\title{
Why Do Most Small Businesses in Liberia Fail
}

\author{
Ahmed Denton \\ Business Department, University of Essex Online, Leeds, UK \\ Email: online.essex.ac.uk
}

How to cite this paper: Denton, A. (2020). Why Do Most Small Businesses in Liberia Fail. Open Journal of Business and Management, 8 , 1771-1815. https://doi.org/10.4236/ojbm.2020.84110

Received: June 11, 2020

Accepted: July 26, 2020

Published: July 29, 2020

Copyright (C) 2020 by author(s) and Scientific Research Publishing Inc. This work is licensed under the Creative Commons Attribution International License (CC BY 4.0).

http://creativecommons.org/licenses/by/4.0/

\begin{abstract}
Small businesses are considered to be the backbone of every economy. If they are not administered effectively, they quickly diminish. There are several factors that result in small business failure. This study examined the reasons for the failure of small businesses in Liberia. Data was collected using questionnaire and the targeted participants were business persons and business students within Liberia. The study revealed that poor business planning is the main factor responsible for the failure of most small businesses in Liberia. Most proprietors of small businesses in Liberia don't plan properly before the commencement of a business. They depend on the day to day reality to run the business which is not good for the future of the business. The study identified ten contributing factors responsible for the failure of small businesses in Liberia. Out of the ten contributing factors, five of them were identified as the top factors. The top five contributing factors include poor business planning, lack of entrepreneurial skills, lack of customer relations, management incompetence and inadequate financing. The study recommended that small business proprietors should conduct a proper business research on the type of business that is to be established and develop a standard business plan that covers all the aspects of the business before commencement. The study also recommended how to address the other top four contributing factors to prevent small businesses from failing in Liberia. However, the information in this study is very essential for the development of the small business sector in Liberia, and other parts of Africa. It is also beneficial to the literature review of small businesses and their failure.
\end{abstract}

\section{Keywords}

Small Business Failure, Business Management, Liberia

\section{Introduction}

\subsection{Background of the Study}

The research was conducted in Liberia and focuses on the failure of small busi- 
nesses. Liberia is a country located on the west coast of Africa and it was founded by the American Colonization Society (ACS) in 1822 (Thompsell, 2018). On July 26, 1847 Liberia became independent, making Liberia the first independent nation in African (Thompsell, 2018). Civil war broke out in Liberia in 1989 and lasted for 14 years, up to 2003 (Thompsell, 2018). The number of small businesses has increased after the civil war, but the rate of failure of small businesses in the country has also significantly increased over the past years (Doe, 2006). Small businesses are at the heart of Liberia's private sector. Their contribution to the economy through local traders enables daily essentials to be available to the remote part of Liberia. It is believed that if small businesses in Liberia are supported and strengthened, they can serve as the vehicle to carry jobs, income and development throughout the country (Building Markets, 2016). The Liberian economy is controlled by small businesses because majority of the citizens depend on small businesses as their main source of income (Building Markets, 2017). Nevertheless, there are several challenges to face when doing business in Liberia. These challenges include poor infrastructure, lack of good road network, lack of electricity, etc. (Building Markets, 2017). Examples of small businesses in Liberia are shown in Table 1 as proposed by Building Markets (2016).

This research is conducted to determine the factors that are responsible for the failure of small businesses in Liberia and to establish possible solutions to prevent these failures from occurring. The identification of these factors helps to develop strategies that can be applied to reduce the high failure rate. This research also helps proprietors of small businesses in Liberia to have a better and more effective approach to how they can operate to obtain sustainability.

\subsection{Problem Statement}

The effective operations of small businesses in Liberia serve as the foundation

Table 1. Types of small businesses in Liberia.

\begin{tabular}{cc}
\hline No. & Types of Small Businesses in Liberia \\
\hline 1 & Construction and Renovation firms \\
3 & Food and Beverages firms \\
4 & Transportation, Logistics and Carrier services \\
5 & Financial and Legal services \\
6 & Security services and equipment \\
7 & Primary Industry (e.g. Agriculture and Fisheries) \\
8 & Office Furniture, Equipment supplies \\
9 & Real Estate and Insurance firms \\
10 & Restaurants and Catering services \\
\hline
\end{tabular}


for the economic development of the country. As stated in the previous Section 1.1, the growth of the economy of Liberia relies on the success of small businesses (Building Markets, 2017). Small businesses owned by Liberians are noted for flourishing at the beginning but after a short period many of them fail (Doe, 2006). There are many reasons for those failures and without addressing them, the economy of the country will not be improved. Some of the reasons for small business failure in Liberia include poor planning, not controlling cash flow, poor infrastructure and road network due to lack of government support, etc. (Doe, 2006; Building Markets, 2017). The current economic situation of the country has created a business environment that is very challenging for small businesses to survive (Dodoo, 2020). Therefore, this research has examined some of the major causes of the failure of small businesses in Liberia and provided recommendations that will help them to continue in existence.

The literature review explains the meaning of business failure and defined small business based on five different worldwide standards. The literature review drew up concepts that were used to identify and address the contributing factors to the failure of small businesses in Liberia. These concepts which make up the theoretical framework of the research examined the internal factors that affect the organizational output (i.e. micro environment) and the external factors outside the firm (i.e. macro environment). To accomplish this, the theoretical framework considered the 7P's marketing mix strategy and the PEST analysis. Ten contributing factors responsible for the failure of small businesses in Liberia were identified and discussed with the relevant citations.

\subsection{Research Question and Objectives}

The research question for this study is "Why Do Most Small Businesses in Liberia Fail"? This research question was selected to uncover the major problems affecting small businesses in Liberia and their consequences.

The objectives of this research are as follows:

1) To critically analyze the factors responsible for the failure of small businesses in Liberia.

2) To evaluate the extent to which the factors identified as being responsible for the failure of small businesses in Liberia affects the businesses.

3) To critically assess whether the factors identified to be responsible for the failure of small businesses in Liberia are controllable or uncontrollable.

4) To develop a guideline that will provide possible solutions to reduce the rate of failure of small businesses in Liberia.

\subsection{Importance of Research Outcome}

The research outcome has increased the knowledge on factors responsible for the failure of small businesses in Liberia and has offered recommendations that can be used to prevent small businesses from failing. In addition, the findings will make significant contribution to the enhancement of small businesses in $\mathrm{Li}$ - 
beria through the understanding of how to develop and implement a proper business plan, acquiring the rightful skills needed to have a successful small business, putting measures in place that ensure employees satisfaction and other important things that can be done to make small businesses to succeed. This research will benefit people that want to start a small business in Liberia and financial institutions that provide loan money to small businesses. The research will also help to reduce the literature gap on the failure of small businesses in Liberia. On the overall, this study will help to improve the small business sector of Liberia.

\section{Literature Review}

\subsection{Introduction}

The life cycle of every business is divided into four stages; Introduction, Growth, Maturity and Decline (Pillemer, 2018). Normally, the introduction and growth stages of the life cycle of most businesses are slow, but with short maturity and quick decline stages (Weitzel \& Jonsson, 1989). Although business failure is difficult to define, most of the definitions are closely related and are focused towards the organizations and individuals (Jenkins \& McKelvie, 2016). This also has to do with the moment that the company ceases to exist, leaving investors and creditors in debts (Jenkins \& McKelvie, 2016; Ucbasaran et al., 2013). The process involved to determine the moment that a business will cease to exist varies from one author to the other, and it is based on how they analyze the phenomenon (Ucbasaran et al., 2013). Some of the literature reviews focused mainly on financial ratios to predict business failure (Altman, 1968; Maricica \& Georgeta, 2012; Longair, 1983). Walters (1957); Sharma and Mahajan (1980); Flint (2019) viewed business failure essentially as having expenses more than the business cash (i.e. as a reservoir of cash). This means that if a business reservoir is empty, the business has failed because it will be considered as bankrupt. Therefore, an enterprise may be regarded as a "failure" when it cannot meet its liabilities (Van Horne, 1977; Gaughan, 2015). A business can also be considered as failure if the overall set goal of management is not met (Business Week, 1971; Schaefer, 2019). In this research Business failure will be considered as the end of a business life cycle due to lack of capital to continue operating (Horton, 2019). This means that if the business can no longer generate revenue and cannot continue to operate under such condition or totally run out of operating funds that cause the business to close.

\subsection{Definition of Small Business}

There is no definite definition for small business, it varies from one geographical and economical composition to the other. In order to be able to define small business, you need to have an understanding of the size, components and benefits that small businesses have on the life of the people (as shown in Table 2), especially on those that are at the grass root level of the country (Adisa et al., 2014). 
Table 2. Definitions of small business.

\begin{tabular}{|c|c|c|}
\hline No. & Country & Definition of Small Business \\
\hline 1 & $\begin{array}{c}\text { European Union } \\
(\mathrm{EU})\end{array}$ & $\begin{array}{l}\text { The European Union (EU) regulations defined small business as any } \\
\text { business that has ten to fifty ( } 10 \text { to } 50 \text { ) employees, with an annual turnover } \\
\text { of greater than two million euro and less than ten million euro (Nikolić et } \\
\text { al., 2015). }\end{array}$ \\
\hline 2 & Albania & $\begin{array}{l}\text { The Albanian legislation also considers small business as any business that } \\
\text { has more than fifty (50) employees with an annual balance sheet of not } \\
\text { more than fifty million euro (Nikolić et al., 2015). }\end{array}$ \\
\hline 3 & Nigeria & $\begin{array}{l}\text { Small business is defined as any business with capital ranging from twenty } \\
\text { thousand naira to thirty million naira (Alaye-Ogan, 2012). The Federal } \\
\text { Ministry of Commence of Nigeria defined small business as a business } \\
\text { capital investment of over seven hundred and fifty thousand naira (Adisa et } \\
\text { al., 2014). }\end{array}$ \\
\hline 4 & Ghana & $\begin{array}{l}\text { According to Ghana Statistical Service (GSS), small business is any } \\
\text { enterprise with less than ten (10) workers (Nkuah et al., 2013). Also } \\
\text { according to the National Board for Small Scale Industries (NBSSI) in } \\
\text { Ghana, small business is any enterprise with not more than nine (9) } \\
\text { workers, has plant and machinery, (excluding land, buildings and vehicles) } \\
\text { but does not exceed ten million Cedis (Nkuah et al., 2013). }\end{array}$ \\
\hline 5 & Liberia & $\begin{array}{l}\text { In Liberia, small business is classified as any enterprise with total number } \\
\text { of employees ranging from four to twenty ( } 4 \text { to 20) (MoCI, 2010). } \\
\text { According to the Liberia Revenue Authority (LRA), small business is any } \\
\text { business with annual revenue of greater than two hundred thousand } \\
\text { Liberian dollars but less than three million Liberian dollars (The New } \\
\text { Dawn, 2019). }\end{array}$ \\
\hline
\end{tabular}

\subsection{Theoretical Framework of the Research}

The theoretical framework for this research will consider two aspects, the micro environment and the macro environment of small businesses. Micro environment consists of factors within an organization that affects the capacities of people that are directly involved or linked to serve the market (Kotler \& dan Armstrong, 2009). The macro environment consists of the economic environment, political environment, socio-cultural environment and technological environment that affects the micro environment of a business (Kotler \& Keller, 2009). To analyze the micro environment, the literature will consider the marketing mix strategy which uses 7P's (Product, Price, Place, Promotion, People, Process and Physical environment) to analyze the small forces that originate from within the business, affecting its ability to serve the customers. The concept of the marketing mix originated from the single $\mathrm{P}$ (Price) of the microeconomic theory (Chong, 2003). The concept was initially stated by Neil Borden in 1953 in his article "The Concept of the Marketing Mix" (Borden, 1964). Borden highlighted twelve elements in his article but they were later summarized into 4P's-Product, Price, Place and Promotion (Goi, 2009). However, the 4P's was only adequate to address the product market and not the service market (Helm \& Gritsch, 2014). To modify the marketing mix $4 \mathrm{P}$ 's to be able to address both product and service 
markets, three additional P's were added to the original 4P's. They are People, Process and Physical environment (Rathod, 2016). The 7Ps marketing mix model was selected because it helps business organizations to identify and review key factors that affect the products or services of a business (Hanlon, 2019). Secondly, the marketing mix is a practical framework which is used to evaluate existing businesses using the appropriate approaches (Hanlon, 2019). The 7Ps marketing mix framework was adapted by Loo and Leung to investigate the service failure of hotels in Taiwan (Loo \& Leung, 2016). For the analysis of the macro environment, this research will consider the PEST analysis. The PEST analysis is the most frequently used approach to analyze the external business environment (Gupta, 2013). The acronym "PEST" represents four factors; political, economic, social and technological (Summut-Bonnici \& Galea, 2015).

\subsection{Factors Responsible for the Failure of Small Businesses}

From previous literature reviews, several factors have been identified to be responsible for the failure of small businesses. For this research, the researcher will consider the below factors for the failure of small businesses in Liberia:

\subsubsection{Poor Business Planning}

One of the major reasons for business failure today is due to poor business planning (Schaefer, 2019). A well planned business should address the mission of the business, the cost structure, the target market for the business, risks of external influences and how to handle them, and the business strengths and weaknesses (Schaefer, 2019). The business plan is developed using knowledge acquired from data collection and analysis, on relevant key performance indicators from existing businesses with similar or exactly the same scope of operations (unctad.org, 2002; Mehralizadeh \& Sajady, 2005). Burns and Dewhurst (1996) state that "most small businesses fail because their plans are sales-oriented and they need a transition in outlook in order to meet customer needs" (Mbonyane, 2006). Most entrepreneurs of small business do not plan properly (Carter, 2019). They depend on the sales to run the business (Mbonyane, 2006). They do not forecast or even plan ahead for future occurrence like introduction of new products that will divert the attention of the customers (Mbonyane, 2006). A study conducted by the Small Business Development Centre in the USA, discovered that lack of proper business planning is responsible for $90 \%$ of small business failures (Bushe, 2019). One of the issues that render a business plan to be poor, is lack of strategic planning. Strategic planning is important because it provides the road map for the execution of the business and identifies the milestones that indicates whether the business is progressing as planned or not (Gartenstein \& Seidel, 2019). Consequently, a lack of strategic planning prevents small businesses from achieving good performance because there are many uncertainties that the business will encounter, and there will also be no guidance for the business to attain its goals (Gumel, 2017). 


\subsubsection{Inadequate Financing}

Financing is the lifeline of every business whether in the beginning stage, developing stage or in a mature stage. The failure of many businesses is as a result of lack of proper financial support to establish them on strong and stable footing (Mehralizadeh \& Sajady, 2005). Most entrepreneurs don't have enough consciousness of the costs required in raising capital (Skripak et al., 2016; Carter, 2019). They do not plan in advance, but rather look for financing just when needed, which is risky for the future of the business (Carter, 2019). Initially, a business's capital may be limited to what its owners can afford from their own source, but as the business starts to grow there might be some financial needs that the owner alone cannot fund, but will require some support from others, like banks, or even to get in shareholders (Mehralizadeh \& Sajady, 2005). According to Jones and Tilley (2003), inadequate financing is one of the obstacles experience by number of new businesses to success throughout the beginning period and during the first year of their operations.

Inadequate financing is a major problem encounter by many small businesses (Carter, 2019). Most owners of small businesses use their own savings or family resources to start the business (Attard, 2019). As the business is established and in operations, they depend on the revenue generated by the business to sustain their family and themselves (Petersen \& Seidel, 2019). One of the reasons for inadequate financing is the requirement setup by banks for the acquisition of loan to start a business (wpfsi.com, 2019). Small business owners are required to submit high value collateral as security to the bank for loan (Adisa et al., 2014). This is very challenging for most owners as they do not have the collateral to give to the bank to obtain loan (Adisa et al., 2014). Inadequate financing has caused many good business ideas to languish (Adisa et al., 2014). Another reason for inadequate financing is the high-interest rates which is requested by banks or microfinance institutions for the acquisition of loans (Kanayo et al., 2013). Most of the small businesses cannot generate revenue to pay back the loan with high-interest rate, and at the same time to sustain the business because it is difficult to make profit (Kanayo et al., 2013). Adequate financing is very critical to the growth, sustenance and survival of all small businesses (Gumel, 2017).

\subsubsection{Lack of Adequate Cash Flow}

Cash flow is the measure of an organization ability to control and maintain the movement of sufficient funding in and out of the business to meet its expenses for the day-to-day activities (Murray, 2019). You can have a great business idea with investors to support the idea, but if you have a poor cash flow management, the business won't survive (Hecht, 2015). Van Aardt et al. (2002) argue that "making and receiving payments is at the heart of a business, so it is essential to have a system that is optimized to maximize cash flow and manage information accurately". Another issue with cash flow is, many business owners cannot genuinely show where their cash has been spent or even forecast their future spend- 
ing (McGregor, 2004).

Proper cash management is very essential for the smooth running of any business. Firms need adequate cash flow to sustain their businesses through the payment for new purchases, payment of bills and accrued operating expenses in general. Effective cash management has to do with the identification and control of cash inflows and cash outflows of a business (Banker et al., 2009). It is very important that every small business should have sufficient cash at all times to prevent disruption to the business. According to Meng (2013), almost 71\% of businesses experience cash flow problems. This is because the managers of small businesses are believed to have more focus on profits rather than on cash flows (Mong, 2011). The failure of small businesses is not only due to firms losing, but also due to lack of adequate cash flow. The Centralian Advocate (2009) revealed that increase in revenue and decrease in inventories do not mean that the business is doing well. A good profit is not necessary to the business if there is no cash to sustain the business. That is why the lack of adequate cash flow results in the failure of many small businesses. As blood is to human beings to survive and stay alive, so is cash flow to a business. Without adequate cash flow the business will collapse and come to an end (Bushe, 2019).

\subsubsection{Management Incompetence}

The failure of most businesses is due to "management inadequacy", which can be related to either management inexperience or incompetence (Perry \& Pendleton, 1983; Schaefer, 2019). The performance of any business is influence by the managerial skills of the human resource (Adisa et al., 2014). The management team of small businesses usually lacks the required experience and expertise, they are mostly dependent on a few individuals, that don't have a formal management or career structure (Adisa et al., 2014). Normally, the business is run and managed by a sole proprietor who does not have any business knowledge but because they have the capital to establish a business, they do it without consulting or employing someone competent to establish and run the business for them (Adisa et al., 2014). According to the report from the U.S. Small Business Administration (SBA), more than $90 \%$ of small businesses failed due to management incompetency (Knotts et al., 2003). This is mainly because the management of small businesses is responsible for the implementation and control of all operational practices which are part of the functions of the managers. A competent management has the ability to forecast the future and put in measures to prevent any potential threat to the business (Mbonyane, 2006).

Most small businesses are initiated by people without the adequate knowledge of business management (Adisa et al., 2014). As the business continues to grow, it will start to encounter lots of challenges that require the right managerial capabilities to address them and prevent the business from failing (Fatoki, 2014). Failure to have a management team with the required skills like problem-solving, effective communication, decision-making, conflict resolution, ne- 
gotiation, etc. will result in business failure (Adisa et al., 2014). The owners of small businesses need to employ managers with the rightful managerial skills. According to Didonet et al. (2012), small businesses with competent management team that possess self-confidence and technical knowledge, attain high growth rates and are successful.

\subsubsection{Lack of Entrepreneurial Skills}

Most entrepreneurs of small businesses don't have the requisite skill to manage the business (Lotich, 2019). As a result of this, many small businesses have collapse because their owners don't have the skills to see the future and manage the business properly (Bushe, 2019). Cromie and John (1983) indicated in their work that the skills required for the growth and development of a business is different from the skills needed to plan and lunch a business. Therefore, entrepreneurial skills are very vital for the initiation and control of businesses in order to prevent failure (Cromie \& John, 1983). Entrepreneurship is a way of thinking, reasoning and acting in order to obtain business opportunities in a holistic approach and to create a balanced leadership (Timmons \& Spinelli, 2007). Lack of entrepreneurial skills prevents small businesses from creating opportunities for production and technological improvement through the invention of new processes, new products, establishment of new market etc. (Timmons \& Spinelli, 2007). Entrepreneurship is the focal point for the development process of every business, especially in the 21 st century. The most important and basic business skills required to successfully operate small businesses and obtain profit are entrepreneurial skills (Marivate, 2014). These skills are needed for the implementation of strategic decisions that results in long term sustainability of the business. Managers of small businesses with entrepreneurial skills ensure the generation of growth, wealth, and well-being by calculating the risk ahead of time (Abdul, 2018).

\subsubsection{Inappropriate Location}

The location of small businesses plays a very important role in terms of the success or failure of the business (Sherman \& Seidel, 2019). If the location of the business is not suitable in terms of customer accessibility, or there are similar businesses within the same location, or the population density is too small compared to the business size, the chance of survival for the business will be very minimal (Sherman \& Seidel, 2019). According to Pickle and Abrahamson (1990) and Mbonyane (2006), owners of small businesses often select the location of their business based on the cost or how convenient the place is to them. In most cases, small business owners select locations based on the availability of an infrastructure close to their resident or due to low rent. This is done usually without even investigating whether there is potential for the business they want to establish to survive and generate revenue. The success of small businesses is a function of the location of the business (Schaefer, 2019). When selecting the location 
for small business, the owner needs to consider the rental cost, the traffic, the convenience of the buyers, crime rate in the neighborhood, target consumers etc. (millforbusiness.com, 2018). The business needs to be located at a place where the customers can easily access, even during rush hours. According to Schaefer (2019), the location of most local businesses is critical to the success of the business.

\subsubsection{Lack of Government Support and Empowerment Role}

Small businesses have a great role to play in the economic growth of every country (Kozak, 2017; Brown, 2018). It should be one of the duties of the government to help entrepreneurs to start new businesses and protect them to continue the business by creating an enabling economic environment (Mehralizadeh \& Sajady, 2005). This includes the creation of physical infrastructures like road, power, water, transportation etc. They also need minimum government regulations, like taxes as low as feasible, implement laws that will give small domestic business leverage over foreign businesses, and help to create a financial sector that will allow businesses to have easy access to funds (Mehralizadeh \& Sajady, 2005). The government should also ensure that small business registration processes are not expensive and free of high level of bureaucracy (Mehralizadeh \& Sajady, 2005). The decentralization of government ministries to provide services at the regional levels, will support businesses and is more cost-effective (Tawney \& Levitsky, 2000). In countries like Malaysia, the government has demonstrated commitment to the development of small and medium businesses. They have made provision to support small and medium businesses with finance through loans, working capital and grants. They have also supported by providing advisory support like conducting research on product development and new business initiatives, marketing and technical support (Gunto \& Alias, 2013). Another country with similar initiative is Botswana. The government of Botswana has put into place measures to support small businesses in order to boost their economic productivity, especially for small businesses that are fully owned by citizens of the country (Mutoko, 2014). Every government is expected to support small businesses by offering tax exemptions, providing safe environment for the establishment and operations of businesses, and to amend business regulations to support the growth of small businesses (Al-Shaikh, 1998). This will help in the prevention of small business failures and help to grow the country's economy at a faster rate.

\subsubsection{Lack of Employee's Satisfaction}

One of the serious problems that is faced by small businesses is the issue of hiring or working with family members (Hubbard \& Hailes Jr., 1988; Mbonyane, 2006). Most times, relatives are hired, but they lack the necessary skills for the smooth operations of the business (Mbonyane, 2006). Small business owners normally do this because they feel that they are doing their relatives a favor and don't need to put them on payroll (Mbonyane, 2006). This can result in their 
relatives involving in stealing the business materials or cash to meet their needs (Springer, 2017). Employee's satisfaction has a significant role to play in terms of business performance, for employees are more loyal and productive when they are satisfied (Hunter \& Tietyen, 1997). Employee's satisfaction is a prerequisite to increase productivity, quality, commitment, responsiveness and customer service (Sageer et al., 2012). When the employees are satisfied, they will stimulate positive actions which will result in improvement of the company's performance. If the owner of a small business fail to create an environment that employees will be encouraged to interact personally, employees will not offer their best support to the business for it to prosper (Longenecker et al., 2003). It is required of the owners of small businesses to create an atmosphere of openness at the workplace towards the employees in order for them to trust the owners and take full responsibility of their work.

\subsubsection{Lack of Customer Relations}

Every business has a responsibility to satisfy its customers, and the customers are classified as one of the important stakeholders (Benn et al., 2016). This requires more than just selling your products to the customer or providing a service. The key focus should be to build relationships with your customers. The Small Business Advisor (1999) and Mbonyane (2006) state that, "the failure of small businesses is due to lack of daily contact with the customers, lack of special promotions, price changes, and lack of new product features". Another issue with customer relations will be lack of a proper medium for customers to communicate complaints to the owner (Mbonyane, 2006). This breakdown in communication can result in customers' dissatisfaction and affect customer relations (Mbonyane, 2006). Customer relation is a vital aspect of business management (DiScipio, 2017). Small businesses that fail to pay attention to customer relations are unable to understand the behavior of the customers (MacDonald, 2019). This is mainly due to poor communication between the business staffs and the customers. Intense communication between the business staffs and the customers improves the performance of the business because it attracts the customers, keeps their loyalty and increases the profitability of the business (Soliman, 2011). Lack of customer relations affects the profitability of small business and prevents the delivery of value to the targeted customers (Babu, 2012). In order to retain customers and attract new ones, small businesses need to implement customer relation management. Most small businesses struggle to attract and retain their customers (Sibanda \& Ndhlela, 2018). This is a complicated task and if successful, it helps companies to gain competitive advantage.

\subsubsection{Ignoring Competition}

In this modern age, all customers are looking for the best products or services (Tracy, 2005; Sukhraj, 2017). This has created a business environment that is highly competitive, with rapid changes in product design and diversity (Tracy, 2005). Small businesses need to keep their focus on the type of deal that is of- 
fered by their competitors. Ignoring competition is dangerous and leads to failure of businesses (Olsen, 2019). The competitor that offers better products, services or prices always prevail because they attract most of the customers (Bushe, 2019). For small businesses to avoid failure, they need to prioritize the competition with other businesses providing similar services or products (Olsen, 2019). In the past, the concept of ignoring competitors was working but currently, this concept is no longer applicable because time has changed. For small businesses to stay in existence, they need to keep their eyes on the competitors and position their products accordingly (Sukhraj, 2017). Focusing on your competitors as an entrepreneur is vital to staying in business. Ignoring your competitors in this modern era leads to business downfall (Prokopets \& Shah, 2019). Things are changing rapidly and new products are being introduced in the market frequently. The only remedy to this problem is to stay competitive and keep your competitors under the radar (Sukhraj, 2017).

\subsection{Conceptual Framework of the Study}

Figure 1 below shows the complete conceptual framework for the factors responsible for the failure of small businesses established from the theoretical framework. In the conceptual framework, 3 of the 7Ps were not considered as key contributing factors to the failure of small businesses in Liberia. This is mainly because the selected contributing factors are only associated to 4Ps (Place,

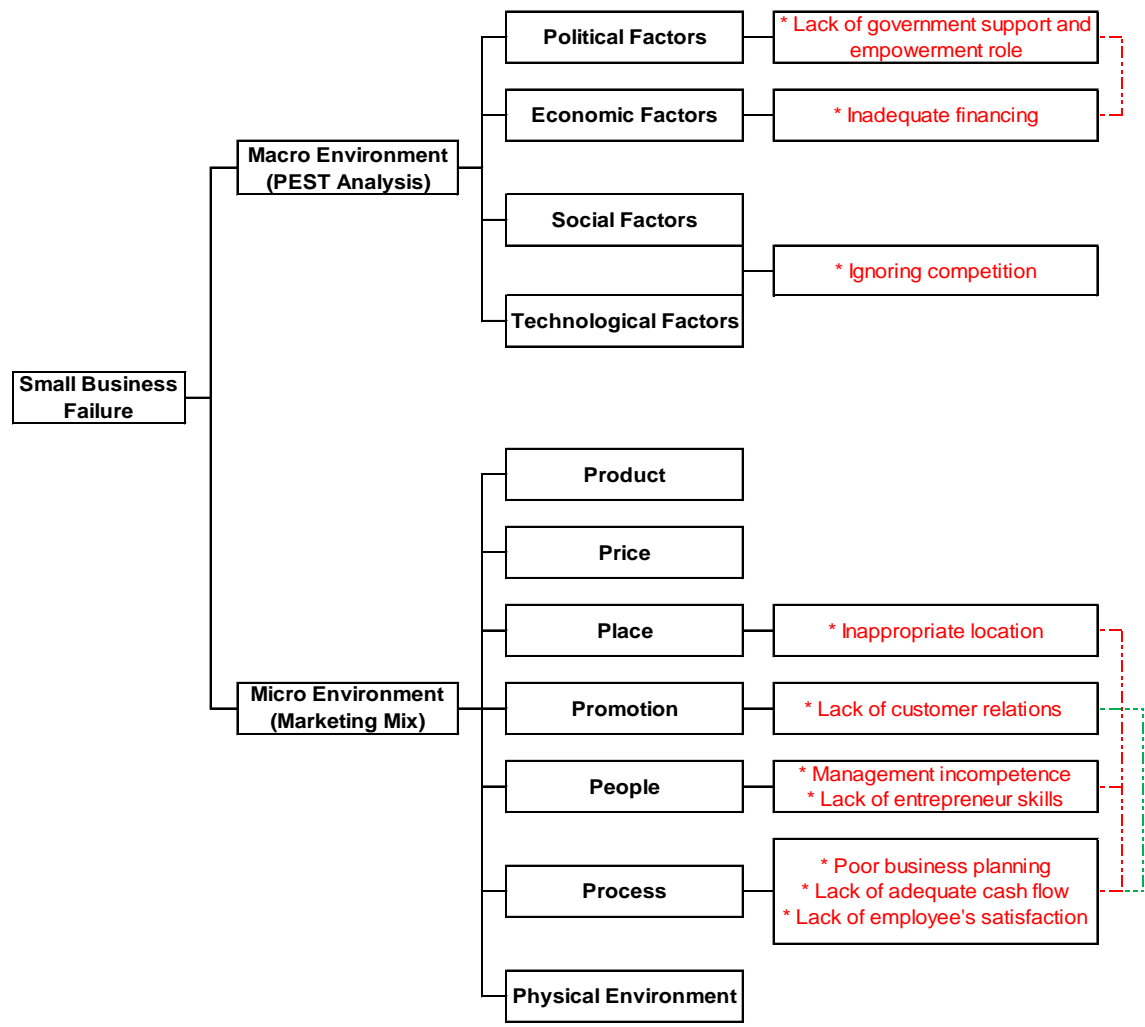

Figure 1. Conceptual framework for the failure of small businesses. 
Promotion, People and Process). Addressing the factors under the 4P's selected will automatically resolve any problem that is associated to the remaining 3Ps (Product, Price, and Physical Environment). There is a relationship between the political and economic factors of the conceptual framework. Ignoring competition is mutually related to the social and technological factors affecting small businesses. There is also a relationship between the contributing factors that fall under the "Process" category of the 7P's marketing mix and that of "Promotion" and "People" categories. Lastly, the factors associated with the "People" category are related to the "Place" category because the decision of proprietors is used to establish the choice of the place for the business.

\section{Research Methodology}

\subsection{Research Philosophy}

Research philosophy refers to a system of beliefs and assumptions about the development of knowledge (Bryman \& Bell, 2015). "Research philosophy is classified as ontology, epistemology and axiology" (Thakurta \& Chetty, 2015). Ontology is defined as the study that is conducted to establish findings about the nature of the world (Snape \& Spencer, 2003). Richards (2003) defines ontology as "the assumptions we make about the kind and nature of reality and what exists". Epistemology has to do with a study that is conducted to address a "what is" or "should be" question concerning an acceptable knowledge in a particular discipline (Bryman, 2008). In the domain of the research philosophy, epistemology is classified as positivism, realism and interpretivism (Thakurta \& Chetty, 2015). Positivism is a branch of the epistemology that has to do with the view that only factual knowledge gained through observation and measurement is trustworthy (Dudovskiy, 2018). The role of the researcher in a positivism study is limited the collection of data and interpretation of the data (Dudovskiy, 2018). This type of study depends on observations that are quantifiable and the data is analyzed using statistical analysis (Dudovskiy, 2018). Realism is another branch of epistemology that has to do with scientific enquiry (Thakurta \& Chetty, 2015). It differs from positivism in that, it depends on independent ideas of reality produced by the human mind (Dudovskiy, 2018), while positivism relies on factual knowledge obtained through scientific measurements (Dudovskiy, 2018). Interpretivist research refers to study that is conducted "to create new, richer understandings and interpretations of social worlds and contexts" (Saunders et al., 2009). "Axiology refers to the role of values and ethics within the research process" (Saunders et al., 2009). This has to do with the role of the values of both the researcher and the research participants in every stage of the research process, which is very essential to the credibility of the research result (Saunders et al., 2009).

The ontological implications for this research are the researcher's belief that most small businesses in Liberia fail and there are factors responsible for their failures. This reflects the belief that there is a social as well as physical reality 
which is associated with the failure of small businesses in Liberia. The epistemological choice of research philosophy for this research is positivism. The epistemology of this research is concerned with how knowledge can be obtained on the reasons for the failure of small businesses in Liberia. Positivism was initially introduced by Auguste Comte a sociologist (Giddens, 1974; Crotty, 2003). Positivism is applicable to any research approach that uses scientific method to human affairs (Grix, 2010). In terms of strength, research conducted using positivism are clear, precise, rigour, standardized and the findings can be generalized (Ernest, 1994). However, there are also some weaknesses. For example, some of the measurements that are developed by positivist researchers are sometimes considerd as artificial and false instead of being correct (Bryman, 2008). Other weaknesses include the prevention to utilize once ability to interpret your experiences and share them with others (Cohen et al., 2007); and the outcome of positivism may be difficult to understand and not applicable to address specific situation (Johnson \& Onwuegbuzie, 2004).

\subsection{Research Approach}

Research approach is the step by step plan that is used for data collection, analysis and interpretation during a research (Chetty, 2016). There are three different types of research approach, namely (Dudovskiy, 2018):

$>$ Inductive

Deductive

$>$ Abductive

An inductive research approach is initiated from a specific observation to broader generalization and theory (Mitchell, 2018). It is sometimes referred to as the "bottom up" approach (Dudovskiy, 2018). The process begins by looking at a specific observation and measure, monitor the patterns and regularities, formulate tentative assumption that can be explored, and finally develop conclusion and theory (Mitchell, 2018). The inductive approach is the direct opposite of the deductive approach (Mitchell, 2018). The deductive approach works from a general perspective to a more specific point. The deductive approach is sometimes referred to as "top-down" approach (Dudovskiy, 2018). The process begins by considering a specific situation that can be tested. During the testing, observations are collected to ascertain the facts. The final stage is the confirmation of the theory after analyzing the data collected (Mitchell, 2018). The abductive approach is used for the explanation of incomplete observations from both the deductive and inductive approaches (Dudovskiy, 2018). For the abductive approach, incomplete observations are converted into experience and reality which give birth to the prediction of truth or a new theory (Mitchell, 2018).

From the previous section on research philosophy, we understood that positivism study involves scientific and systematic approach and uses quantitative methodology (Mukherji \& Albon, 2014). Quantitative methodology utilizes statistics to analyze and test data to establish findings. The suitable research ap- 
proach to be used for the analysis of this type of data is the deductive approach (Chetty, 2016). When using the deduction approach, the researcher will have to identify the issue to be investigated and develop questionnaire to collect data from those assumptions to be affected by it (Saunders et al., 2015). Some of the benefits of the deductive approach include the collection of latest data for analysis to establish facts (Saunders et al., 2015). It enables researchers to explain the causal relationship between concepts and variables (Dudovskiy, 2018); and it also allows for research findings to be generalized to a certain extent (Dudovskiy, 2018). As for limitations, two of the weaknesses of the deductive approach are, it does not encourage extensive thinking and it limits the scope of creativity (David, 2016).

\subsection{Research Design}

Research design refers to the set of methods and procedures used for collecting and analyzing data for a research (McMillan \& Schumacher, 2001). The research design should logically come from the research question, objectives, philosophy and approach (Akhtar, 2016). It should also consider whether the nature of the research is exploratory, descriptive or explanatory (Akhtar, 2016). Descriptive research is a research that is conducted to describe a population, situation or phenomenon in an accurate and systematic manner (McCombes, 2019). This may include a research that is conducted to describe social events or social situations, etc. (Akhtar, 2016). The researcher will observe and describe the findings of what they observed. This type of research provides answers to questions like what, who, where, how and when, but does not answer a why question (McCombes, 2019). Explanatory research is a research that is conducted to explore a new universe, one that has not been researched earlier (Akhtar, 2016). For instance, a research that is conducted to investigate why men commit more domestic violence than the women. Exploratory research is conducted to establish an insight into a particular phenomenon (Akhtar, 2016). A problem is formulated, followed by an investigation to establish the fact (Akhtar, 2016). It is mainly conducted for cases where there has not been any earlier research or studies to serve as a reference (Akhtar, 2016).

The exploratory research design is normally used to conduct an initial research into a hypothetical or theoretical idea (Kawalczyk, 2003). Among the different types of research design, the exploratory research design is more suitable for this research. The exploratory research is useful for gaining background information on a particular topic (Kawalczyk, 2003). It is also suitable to address research questions of all types (what, why, how). On the other hand, there are some weaknesses of the exploratory research, these include (Kawalczyk, 2003):

> The utilization of small sample sizes to represent a large population.

$>$ The nature of the research enables the researcher to provide a definitive conclusion on the findings, of which in reality only provide insight.

The research leads to tentative results with limited value to decision-makers. 


\subsection{Research Strategy}

Research strategy is the plan that is utilized by the researcher to answer the research questions (Saunders et al., 2009). There are seven different types of research strategies and they are experiments, surveys, case studies, ethnography, grounded theory, active research and archival research (Datt \& Chetty, 2016) Three of the seven research strategies (i.e. active research, ethnography, and archival research) are based on the inductive research approach, two (i.e. case study and grounded theory) are based on the abductive research approach, and the last two (i.e. experiment and survey) are based on the deductive research approach (Datt \& Chetty, 2016). In Section 3.3, the selected research approach is the deductive approach. Therefore, the suitable research strategy for this research is survey. Survey is mostly used when conducting a research that is business and management related (Datt \& Chetty, 2016). Surveys are conducted through the utilization of questionnaire to a sample of participants from a selected population (Rodrigo, 2017). Survey is very effective in collecting different types of data, ranging from small to large numbers (Rodrigo, 2017). Survey is cost effective; it provides data that can be analyzed statistically without any problem because all the participant's response can be arranged in a standardized manner; and it gives greater precision to data collected during analysis (Sincero, 2012). In terms of disadvantages, Survey is not suitable for dealing with controversial issues that requires more diverse views; and usage of inappropriate questions (Sincero, 2012).

The questionnaire is formulated with close questions to enable the researcher to collect quantitative data which will be analyzed statistically. The questionnaire is also designed in a way that all the contributing factors identified in the literature review are included. This is to ensure that the relevant data needed to address the assumption of this research is captured during the survey process. Questionnaire is a very important tool for data collection. It is inexpensive to collect data for a large population and it is easy to use because the information collected are standardized (McLeod, 2018). It also allows easy analysis of results and permits that researcher to ask as many questions as possible (Debois, 2019). In terms of limitations, sometimes participants may ignore certain questions and if the rightful questions are not asked in the questionnaire, the intent of the research will not be achieved (McLeod, 2018). Another limitation could be the inability to fully capture emotional responses or feelings (Debois, 2019).

The questionnaire contains five different types of questions. The first is to identify the contributing factors, the second to rank the contributing factors, the third to establish whether the contributing factors are controllable or not, the fourth to obtain a deeper insight of the participants views on some of the things that leads to the failure of small businesses in Liberia. Likert scale questions were used in order to achieve this goal. Likert scale question is normally used to measure the attitudes and opinions of the participants (Glen, 2015). Finally, the fifth is the percentage rating questions that examine to what extinct some of the 
root causes are not managed by small businesses in Liberia. Table 3 shows the question numbers and the associated contributing factor from the literature review.

\subsection{Data Collection Methods}

Data collection refers to the process of gathering relevant information to provide answers to the research question, hypothesis of the research and evaluate the findings (Dudovskiy, 2018). The data collection method is divided into two categories (Dudovskiy, 2018):

Secondary data collection-data collected previously by other researchers for some other purpose (Saunders et al., 2015). Secondary data include available data in sources like books, newspapers, magazines, journals, online portal etc. (Dudovskiy, 2018).

$>$ Primary data collection-the collection of new data for research purpose (Saunders et al., 2015). The primary data collection is divided into two groups, quantitative and qualitative research methods (Dudovskiy, 2018). The quantitative research method has to do with the collection of numerical data and mathematical calculations, while the qualitative research method deals with non-numerical data, and has to do with feelings, emotions etc. (Dudovskiy, 2018).

Primary data is collected from first-hand-experience and it cannot be altered by human activities (Kabir, 2016). For research that involves survey, it is required to gather primary data that will be statistically analyzed (Kabir, 2016). Therefore, the researcher will use the primary data collection method to collect the field data using questionnaire. The primary data collection method was selected for this research because there is no existing data on the research. Though

Table 3. Contributing factors and questionnaire.

\begin{tabular}{cc}
\hline Question Numbers & Contributing Factor (s) \\
Q.1 - Q.3 & $\begin{array}{c}\text { All the ten contributing factors considered in this research, } \\
\text { responsible for the failure of most small businesses in Liberia. }\end{array}$ \\
Q.4 - Q.6 & Poor Business Planning \\
Q.7 - Q.9 & Inadequate Financing \\
Q.10 - Q.12 & Lack of Adequate Cash Flow \\
Q.13 - Q.15 & Management Incompetence \\
Q.16 - Q.18 & Lack of Entrepreneurial Skills \\
Q.19 - Q.21 & Inappropriate Location \\
Q.22 - Q.24 & Lack of Government Support and Empowerment Role \\
Q.25 - Q.27 & Lack of Employees Satisfaction \\
Q.28 - Q.30 & Lack of Customer Relations \\
Q.31 - Q.33 & Ignoring Competition
\end{tabular}


the primary data collection method is good for this research, it is important to note that there are some disadvantages of this method. The primary data collection is expensive and it is also limited to time, number of participants and geographical location (Bradley, 2013).

\subsection{Sampling}

According to Salkind (2003), population refers to a group of potential participants to whom you want to generalize the results of the study. The subset of the population is called sample, and the process of selecting the sample is called sampling (Singh, 2018). The sample size is the number of elements in the sample (Singh, 2018). Sampling techniques can be divided into two groups (Singh, 2018; Taherdoost, 2016):

- Probability Sampling or Random Sampling-This group of sampling techniques provides equal chance to every item in the population to be included in sample (Singh, 2018). The probability sampling is the best to prevent bias sampling, but it is the most expensive due to the time and energy required for a given level of sampling error (Singh, 2018).

- Non-probability Sampling is mainly used for research design that involves case study and qualitative research (Taherdoost, 2016). The following sampling techniques are under the non-probability sampling category (Taherdoost, 2016):

○ Quota sampling

- Snowball sampling

- Convenience sampling

- Purposive or judgmental sampling

This research will apply the simple random sampling technique, which means that the entire population of the research has equal probability of being included in the sample (Taherdoost, 2016). The random sampling technique was chosen to avoid bias sampling and to a representative sample of the targeted participants. The research will focus on small Liberian businesses proprietors and students studying business management at various Universities within Liberia. Business proprietors and business students will be selected at random. The total population for this research is approximately 500 participants, but the appropriate sample size for this research is 237 participants.

\subsection{Data Analysis Methods}

Data analysis is the transformation of data collected during a research into meaningful information (Bhatia, 2018). According to Perez (2019), "data analysis is the process of evaluating data using logical and analytical reasoning to carefully examine each component of the data collected or provided". Data analysis methods can be divided into two main methods. They are, qualitative data analysis and quantitative data analysis (Perez, 2019):

Qualitative data analysis-refers to the collection of data and information, 
and their interpretations. Bryman and Bell (2015) emphasize that this type of research usually focusses on words rather than quantification in all collection and analysis of data.

$>$ Quantitative data analysis-focuses on the development of conclusion from existing data that is proven statistical using quantitative methods (Bryman \& Bell, 2015).

Mixture of qualitative and quantitative analysis-this is a case were the researcher chooses to analyze his/her research data using both qualitative and quantitative methods for the same research.

From Section 3.3, research approach, the suitable research approach for this research is the deductive approach (positivism) which involves quantitative methodology (Mukherji \& Albon, 2014). Therefore, the researcher will use the quantitative data analysis method for the analysis of the data that will be collected. Descriptive statistics will be applied as the statistical technique for this research. Descriptive statistics was selected because it is used to present quantitative data in a manageable form, and it helps to simplify large data in a sensible way (Trochim, 2020). The quantitative data analysis has advantages and disadvantages. Quantitative data analysis is cost effective, it provides high representativeness and the data collected can be easily analyzed statistically (Almeida et al., 2017). In terms of disadvantages, it is time consuming and doesn't account for changes in emotion or behavior of the participants (Almeida et al., 2017).

\subsection{Reliability and Validity}

Hussey and Hussey (1997: p. 57) define reliability as "the instrument which measures the repetition of the research findings", whereas validity as the extent to which research findings accurately represent what is really happening in the situation. The difference between reliability and validity are: reliability deals with the consistency of the research measurements and validity deals with the accuracy of the research measurements (Middleton, 2019). Reliability tells you the extent to which the results of a research can be repeated under the same condition (Middleton, 2019). Validity ensures that the research findings are actually what is supposed to be achieved (Middleton, 2019). An example will be the medical thermometer. It is reliable to measure the same temperature each time it is used, but if it is a degree off the actual calibration, it will not be valid because you cannot obtain the correct temperature (Glen, 2016).

To ensure the reliability and validity of this research, the research questionnaire was formulated in a way that allows the answers of the participants to be computed statistically during the analysis of the data and if the research is repeated, the same findings can be obtained. The questionnaire also contains closed ended questions which ensure that the research findings are actual what the researcher was looking to establish. The collection of data was done with care and the selected participants were people that are knowledgeable of business management and the running of small businesses. 


\subsection{Ethics}

Research ethics is defined as the act of doing what is morally and legally right in research (Praveen \& Showkat, 2017). Research ethics are the norms required to distinguish between right and wrong when conducting a research (Praveen \& Showkat, 2017). Ethics addresses the difference between the acceptable and unacceptable behavior when conducting a research (Resnik, 2015). For example, it is not ethical to expose the information provided by the participants to another person. Ethics is very vital to every research. It guarantees how participants of a research will be treated, and clarify the activities in which we should or should not engage the participant (Bryman \& Bell, 2015). Ethical approval was obtained from the supervisor and the head of business department at the university before the commencement of data collection. The documents submitted for the ethical approval include: consent form, research proposal, participant debrief sheet, participant information sheet, risk assessment and research questionnaire.

\subsection{Limitations}

The researcher has identified the following limitations associated to this research:

1) This research will only allow participants from two groups of people, business persons and business students. The view of others from different discipline might be different from the two groups. Also, the sample size does not allow all business persons and business students to partake. The sample will be collected at random which might have an impact on the findings.

2) The conclusions and recommendations from the research are based on the research findings which were developed through statistical analysis of the data collected and nothing else. There are no relevant secondary data to reference.

3) The questionnaire is comprised of close ended questions which prevents the participants from providing more information even if they have the ability to do so.

\section{Research Findings and Discussion}

\subsection{Introduction}

This chapter contains information on the data collection process, the data analysis, the research findings, and how the research findings are related to the literature review. The data collection started on January 2, 2020 and ended on January 19, 2020. Data was collected using the designed questionnaire from different parts of Liberia, which includes Monrovia, Buchanan and Kakata. The total number of participants was 237 out of a target of 250 participants, comprising both business students and business persons. The total number of business students that participated was 71 and that of business persons was 166 . The summary of the data collection is shown in Table 4 . 
Table 4. Data collection summary.

\begin{tabular}{cccc}
\hline \multicolumn{3}{c}{ SUMMARY OF DATA COLLECTION } \\
\hline No. & & Description & Comment \\
\hline 1 & Date & Data collection period & January 2, 2020 to January 19, 2020 \\
2 & Participant & Total participant & 237 \\
3 & & Business student & 71 \\
4 & Category & Business person & 166 \\
5 & & Male & 157 \\
6 & Gender & Female & 80 \\
7 & & 18 yrs - 30 yrs & 103 \\
8 & Age range & 31 yrs - 49 yrs & 108 \\
9 & & 50 years above & 26 \\
\hline
\end{tabular}

\subsection{Data Analysis}

From the general analysis of the data collected, the following findings were obtained:

1) The top five factors responsible for the failure of small businesses in Liberia are highlighted in Table 5 (Graph 1).

2) The top five factors in descending order, from the highest magnitude to the lowest are shown in Table 6.

3) Average of $55 \%$ of the participants agree that all the other nine contributing factors to the failure of small businesses in Liberia are controllable except for the "Lack of government support and empowerment role" which $53 \%$ of the participant agree to be uncontrollable (as shown in Table 7, Graph 2).

4) The research findings revealed that most entrepreneurs of small businesses in Liberia do not plan properly. They do not forecast or plan ahead, but rather depend on sales to run the business. Average of $58 \%$ of the participants strongly agree to this finding and $52 \%$ of the participants accepted that over $75 \%$ of small businesses in Liberia operate without proper business plan (see Table 8).

5) The research findings revealed that the failure of many small businesses in Liberia is due to lack of proper financial support. Average of 55\% of the participants strongly agree to this finding and $32 \%$ of the participants accepted that $50 \%-75 \%$ of small business owners in Liberia do not have the consciousness of raising capital (see Table 9).

6) The research findings revealed that most of the entrepreneurs of small businesses in Liberia are not knowledgeable of projecting their business cash flow. They do not plan their future spending and there is no proper control of the business's cash flow. Average of $47 \%$ of the participants strongly agree to this finding and $44 \%$ of the participants accepted that over $75 \%$ of Liberian small business owners do not have knowledge to correctly forecast their monthly cash flow (see Table 10). 
Table 5. Contributing factors and selection frequency.

\begin{tabular}{lccc}
\hline \multicolumn{4}{c}{ GENERAL ANALYSIS } \\
\hline No. & Contributing Factors & Frequency & \% of Total Participant \\
\hline 1 & Poor business planning & 210 & $17.7 \%$ \\
2 & Lack of entrepreneurial skills & 162 & $13.7 \%$ \\
3 & Lack of customer relations & 156 & $13.2 \%$ \\
4 & Management Incompetence & 135 & $11.4 \%$ \\
5 & Inadequate financing & 108 & $9.1 \%$ \\
6 & Ignoring competition & 101 & $8.5 \%$ \\
7 & Inappropriate business location & 99 & $8.4 \%$ \\
8 & Lack of adequate cash flow & 96 & $8.1 \%$ \\
9 & Lack of employee's satisfaction & 63 & $5.3 \%$ \\
10 & Lack of government support and empowerment role & 55 & $4.6 \%$ \\
& & 1185 & $100 \%$ \\
\hline
\end{tabular}

Table 6. Top five contributing factors average ranking.

\begin{tabular}{lcc}
\hline \multicolumn{3}{c}{ Ranged from highest magnitude to lowest } \\
\hline No. & Contributing Factors & Average ranking \\
\hline 1 & Poor business planning & 2 \\
2 & Inadequate financing & 2.7 \\
3 & Management Incompetence & 3.1 \\
4 & Lack of entrepreneurial skills & 3.2 \\
\hline
\end{tabular}

Table 7. Contributing factors control analysis.

\begin{tabular}{|c|c|c|c|c|}
\hline \multicolumn{5}{|c|}{ GENERAL ANALYSIS } \\
\hline No. & Contributing Factors & Controllable & Partially Controllable & Uncontrollable \\
\hline 1 & Poor business planning & 181 & 19 & 24 \\
\hline 2 & Lack of entrepreneurial skills & 98 & 38 & 88 \\
\hline 3 & Lack of customer relations & 137 & 38 & 49 \\
\hline 4 & Management Incompetence & 110 & 45 & 69 \\
\hline 5 & Inadequate financing & 107 & 56 & 61 \\
\hline 6 & Ignoring competition & 119 & 38 & 67 \\
\hline 7 & Inappropriate business location & 131 & 39 & 54 \\
\hline 8 & Lack of adequate cash flow & 103 & 41 & 80 \\
\hline 9 & Lack of employee's satisfaction & 116 & 43 & 65 \\
\hline 10 & $\begin{array}{l}\text { Lack of government } \\
\text { support and empowerment role }\end{array}$ & 56 & 50 & 118 \\
\hline
\end{tabular}


Table 8. Participants response to finding \#4.

\begin{tabular}{|c|c|c|c|c|c|c|c|}
\hline Finding \# & Question \# & Main Idea & Strongly agree & Agree & $\begin{array}{c}\text { Neither agree } \\
\text { nor disagree }\end{array}$ & Disagree & Strongly disagree \\
\hline \multirow{4}{*}{4} & Q4 & Poor planning & 150 & 68 & 10 & 4 & 5 \\
\hline & Q5 & Poor planning/no forecast & 125 & 96 & 6 & 4 & 6 \\
\hline & & & Over $75 \%$ & $50 \%-75 \%$ & $25 \%-49 \%$ & \multicolumn{2}{|c|}{ Less than $25 \%$} \\
\hline & Q6 & Poor planning/business operations & 123 & 77 & 21 & \multicolumn{2}{|r|}{16} \\
\hline
\end{tabular}

Table 9. Participants response to finding \#5.

\begin{tabular}{|c|c|c|c|c|c|c|c|}
\hline Finding \# & Question \# & Main Idea & Strongly agree & Agree & $\begin{array}{c}\text { Neither agree } \\
\text { nor disagree }\end{array}$ & Disagree & $\begin{array}{l}\text { Strongly } \\
\text { disagree }\end{array}$ \\
\hline \multirow{4}{*}{5} & Q7 & Improper financial support & 103 & 87 & 24 & 16 & 7 \\
\hline & Q9 & Business survival/financing & 156 & 71 & 6 & 2 & 2 \\
\hline & & & Over $75 \%$ & $50 \%-75 \%$ & $25 \%-49 \%$ & \multicolumn{2}{|c|}{ Less than $25 \%$} \\
\hline & Q8 & Raising capital/no awareness & 77 & 101 & 35 & \multicolumn{2}{|c|}{24} \\
\hline
\end{tabular}

Table 10. Participants response to finding \#6.

\begin{tabular}{|c|c|c|c|c|c|c|c|}
\hline Finding \# & Question \# & Main Idea & Strongly agree & Agree & $\begin{array}{c}\text { Neither agree } \\
\text { nor disagree }\end{array}$ & Disagree & $\begin{array}{l}\text { Strongly } \\
\text { disagree }\end{array}$ \\
\hline \multirow{4}{*}{6} & Q10 & Entrepreneurs/without cash flow knowledge & 104 & 98 & 22 & 10 & 3 \\
\hline & Q12 & Business owners/no cash flow knowledge & 119 & 96 & 12 & 6 & 4 \\
\hline & & & Over $75 \%$ & $50 \%-75 \%$ & $25 \%-49 \%$ & \multicolumn{2}{|c|}{ Less than $25 \%$} \\
\hline & Q11 & Cash flow impact/no spending plan & 104 & 95 & 29 & \multicolumn{2}{|c|}{9} \\
\hline
\end{tabular}

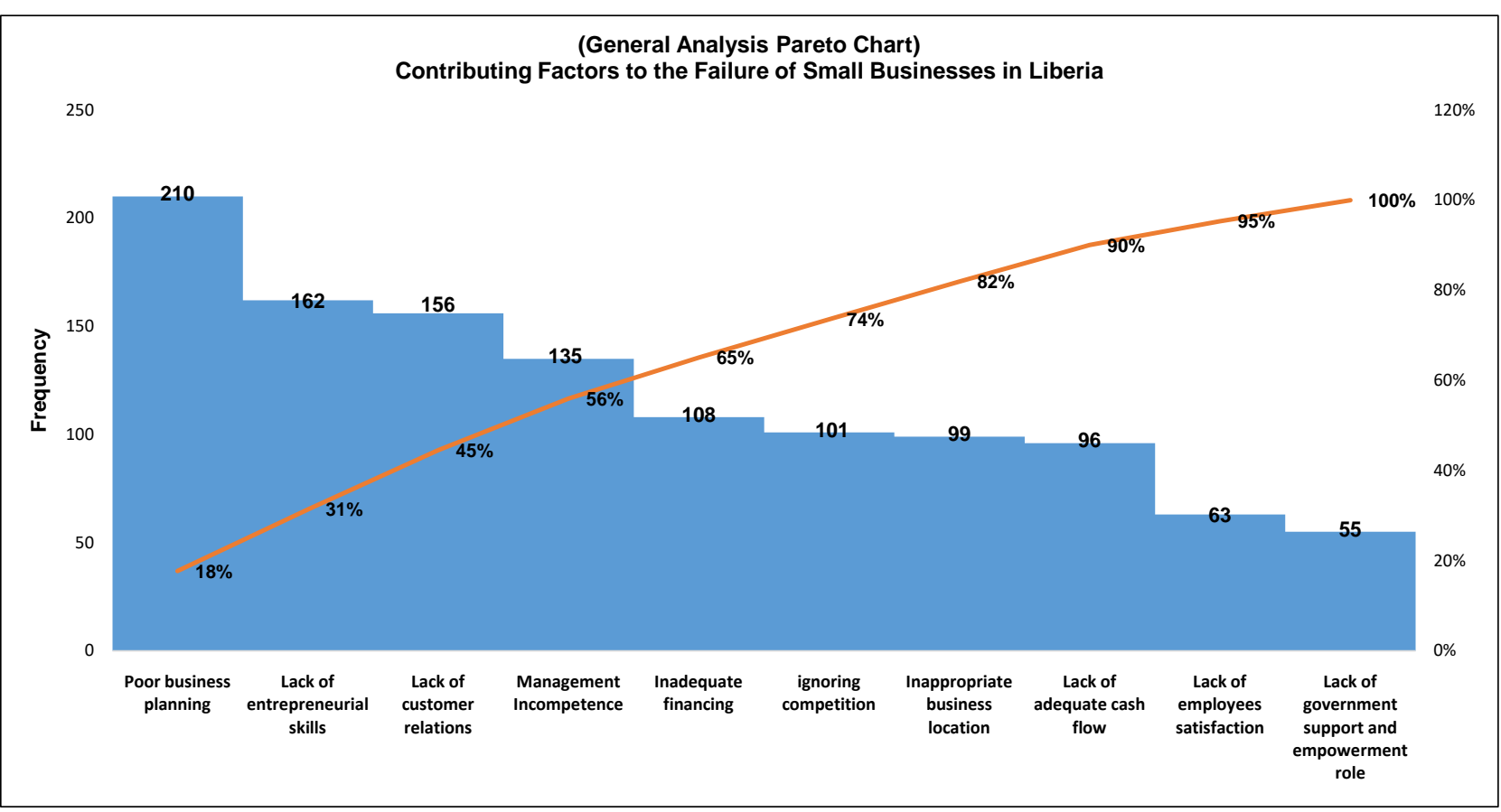

Graph 1. Contributing factors analysis-Pareto graph. 


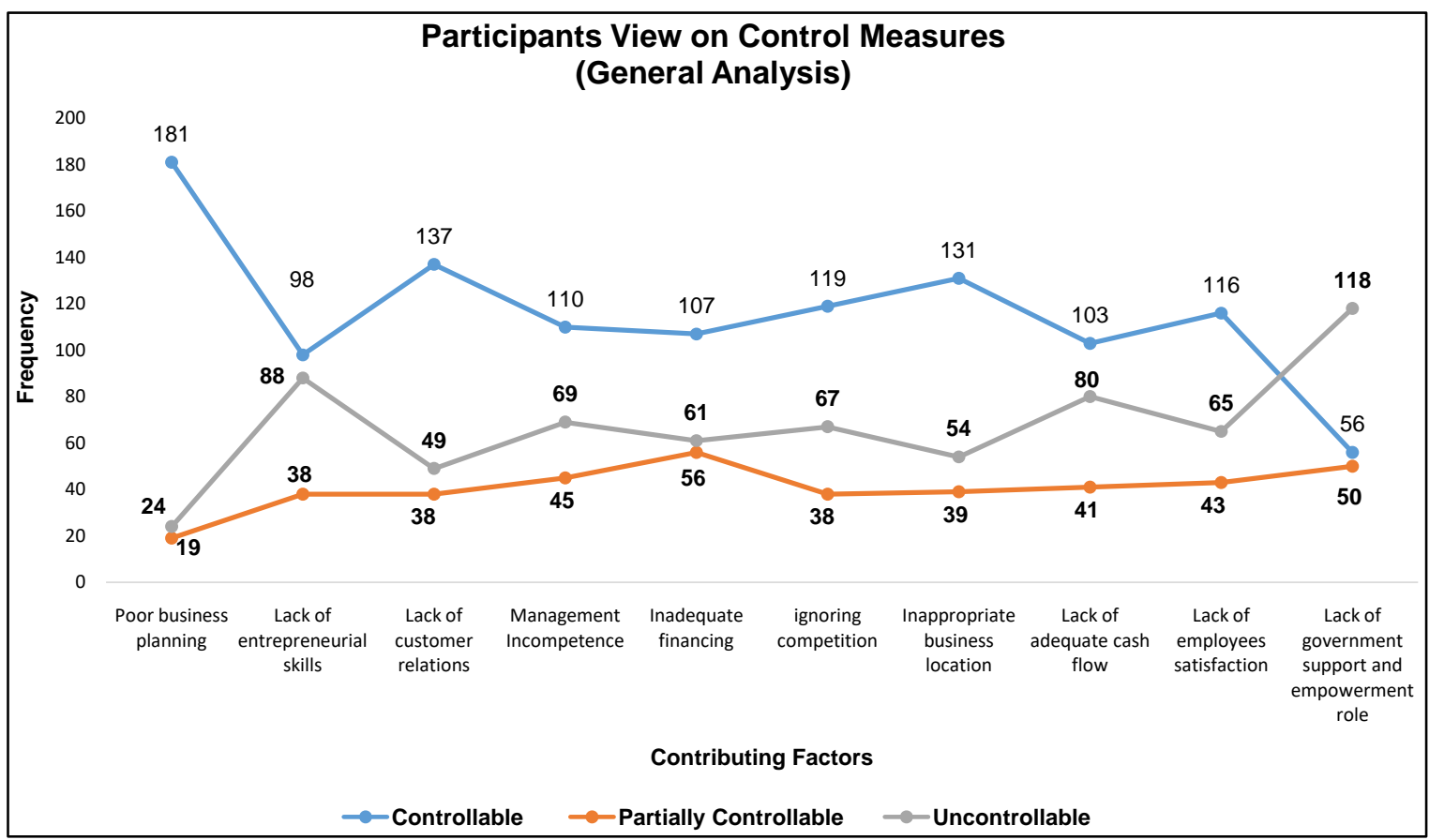

Graph 2. Participants view on control measures.

7) The research findings revealed that the failure of most small businesses in Liberia is due to management inadequacy. They lack the experience and expertise to run a business. Average of $47 \%$ of the participants strongly agree to this finding and $43 \%$ of the participants accepted that over $75 \%$ of small businesses in Liberia have the problem of management inadequacy (see Table 11).

8) The research findings revealed that most of the owners of small businesses in Liberia lack entrepreneur skills which are very important for the ignition and control of small businesses to prevent failure. Average of $55 \%$ of the participants strongly agree to this finding (see Table 12).

9) The research findings revealed that the location of small business plays a very important role in the success of the business. It also confirms that the buyer population and the amount of competitors are key factors to consider when selecting an appropriate business location. Average of 54\% of the participants strongly agree to this finding and $37 \%$ of the participants accepted that over $75 \%$ of the location of small businesses in Liberia are mostly selected based on the closeness to the owner's resident or due to low rental fee (see Table 13).

10) The research findings revealed that most small businesses in Liberia fail because of lack of government support and empowerment. The findings also revealed that failure on the part of the government to implement special laws that gives small domestic businesses leverage over foreign businesses is also responsible for the failure of small businesses in Liberia. Average of $49 \%$ of the participants strongly agree to this finding (see Table 14).

11) The research findings revealed that the hiring of family members that lack the required business skills is one of the main reasons for the failure of small 
Table 11. Participants response to finding \#7.

\begin{tabular}{|c|c|c|c|c|c|c|c|}
\hline Finding \# & Question \# & Main Idea & Strongly agree & Agree & $\begin{array}{c}\text { Neither agree } \\
\text { nor disagree }\end{array}$ & Disagree & Strongly disagree \\
\hline \multirow{4}{*}{7} & Q13 & Management inadequacy & 117 & 94 & 16 & 6 & 4 \\
\hline & Q15 & Business inexperience & 105 & 93 & 24 & 11 & 4 \\
\hline & & & Over $75 \%$ & $50 \%-75 \%$ & $25 \%-49 \%$ & \multicolumn{2}{|c|}{ Less than $25 \%$} \\
\hline & Q14 & Management inadequacy & 102 & 82 & 44 & \multicolumn{2}{|r|}{9} \\
\hline
\end{tabular}

Table 12. Participants response to finding \#8.

\begin{tabular}{cccccccc}
\hline Finding \# & Question \# & Main Idea & Strongly agree & Agree & $\begin{array}{c}\text { Neither agree } \\
\text { nor disagree }\end{array}$ & $\begin{array}{c}\text { Disagree } \\
\text { Strongly } \\
\text { disagree }\end{array}$ \\
\hline \multirow{2}{*}{8} & Q16 & No entrepreneurial skills & 119 & 101 & 13 & 4 & 0 \\
& Q17 & Business future/no entrepreneurial skills & 131 & 91 & 12 & 1 & 2 \\
& Q18 & Business management/no entrepreneurial skills & 138 & 85 & 10 & 2 & 2 \\
\hline
\end{tabular}

Table 13. Participants response to finding \#9.

\begin{tabular}{|c|c|c|c|c|c|c|c|}
\hline Finding \# & Question \# & Main Idea & Strongly agree & Agree & $\begin{array}{c}\text { Neither agree nor } \\
\text { disagree }\end{array}$ & Disagree & $\begin{array}{l}\text { Strongly } \\
\text { disagree }\end{array}$ \\
\hline & Q19 & Business location/business failure & 134 & 85 & 11 & 7 & 0 \\
\hline & Q20 & Business location/selection criteria & 123 & 95 & 14 & 4 & 1 \\
\hline & & & Over $75 \%$ & $50 \%-75 \%$ & $25 \%-49 \%$ & \multicolumn{2}{|c|}{ Less than $25 \%$} \\
\hline & Q21 & Business location/selection choice & 88 & 85 & 39 & \multicolumn{2}{|c|}{25} \\
\hline
\end{tabular}

Table 14. Participants response to finding \#10.

\begin{tabular}{|c|c|c|c|c|c|c|c|}
\hline Finding \# & Question \# & Main Idea & $\begin{array}{l}\text { Strongly } \\
\text { agree }\end{array}$ & Agree & $\begin{array}{c}\text { Neither agree } \\
\text { nor disagree }\end{array}$ & Disagree & $\begin{array}{l}\text { Strongly } \\
\text { disagree }\end{array}$ \\
\hline \multirow{3}{*}{10} & Q22 & Government/business support & 103 & 89 & 28 & 12 & 5 \\
\hline & Q23 & Business failure/lack of government support & 141 & 61 & 16 & 16 & 3 \\
\hline & Q24 & Government support/special laws & 104 & 87 & 22 & 19 & 5 \\
\hline
\end{tabular}

businesses in Liberia. The findings also revealed that the failure of small businesses in Liberia is due to lack of good salary scheme for employees that result in major stealing of the business assets. Average of $47 \%$ of the participants strongly agree to these findings, and $48 \%$ of the participants accepted that over $75 \%$ of small businesses in Liberia lack employee satisfaction (see Table 15).

12) The research findings revealed that most small businesses in Liberia fail due to lack of customer relations as a result of lack of daily contact with customers, lack special promotions and lack of new features. $46 \%$ of the participants strongly agree and $49 \%$ of the participants agree to this finding. $37 \%$ of the participants accepted that $50 \%-75 \%$ of small businesses in Liberia lack customer relations (see Table 16). 
Table 15. Participants response to finding \#11.

\begin{tabular}{|c|c|c|c|c|c|c|c|}
\hline Finding \# & Question \# & Main Idea & Strongly agree & Agree & $\begin{array}{l}\text { Neither agree } \\
\text { nor disagree }\end{array}$ & Disagree & $\begin{array}{l}\text { Strongly } \\
\text { disagree }\end{array}$ \\
\hline \multirow{4}{*}{11} & Q25 & Business failure/hiring of family members & 120 & 93 & 16 & 8 & 0 \\
\hline & Q26 & Business failure/poor salary scheme & 103 & 91 & 23 & 15 & 5 \\
\hline & & & Over $75 \%$ & $50 \%-75 \%$ & $25 \%-49 \%$ & \multicolumn{2}{|c|}{ Less than $25 \%$} \\
\hline & Q27 & Lack of employee's satisfaction & 113 & 85 & 27 & \multicolumn{2}{|c|}{12} \\
\hline
\end{tabular}

Table 16. Participants response to finding \#12.

\begin{tabular}{|c|c|c|c|c|c|c|c|}
\hline Finding \# & Question \# & Main Idea & Strongly agree & Agree & $\begin{array}{c}\text { Neither agree } \\
\text { nor disagree }\end{array}$ & Disagree & $\begin{array}{l}\text { Strongly } \\
\text { disagree }\end{array}$ \\
\hline \multirow{4}{*}{12} & Q28 & Business failure/poor customer relations & 108 & 102 & 16 & 7 & 4 \\
\hline & Q29 & Business failure/lack of promotion & 87 & 116 & 25 & 8 & 1 \\
\hline & & & Over $75 \%$ & $50 \%-75 \%$ & $25 \%-49 \%$ & \multicolumn{2}{|c|}{ Less than $25 \%$} \\
\hline & Q30 & Lack of customer relations & 87 & 99 & 37 & \multicolumn{2}{|c|}{14} \\
\hline
\end{tabular}

13) The research findings revealed that most small businesses in Liberia fail because they ignore competition. $49 \%$ of the participants agree and $45 \%$ of the participants strongly agree to the finding. $46 \%$ of the participants accepted that over $75 \%$ of small businesses in Liberia ignore competition (see Table 17).

\subsection{Analysis of Research Findings}

The data collected for this research was analyzed in different segments. This includes analysis based on the view of the general participants, by category, by gender and by age range. The outcome of the various segments of analyses revealed that most of the findings repeated themselves with little deviation in some instances. It was also proven by the findings that the ten contributing factors selected for this research are truly responsible for the failure of small businesses in Liberia. Below is the summary of the analysis of the research findings:

1) Poor business planning was identified to be the main contributing factor to the failure of small businesses in Liberia for all the different segments of analyses. It was also identified by all the segments of analyses to be the contributing factor with the highest magnitude for the failure of small businesses in Liberia (see Table 19).

2) The top five contributing factors identified by the research findings to be responsible for the failure of small businesses in Liberia are poor business planning, management incompetence, lack of customer relations, lack of entrepreneurial skills and inadequate financing. They were identified by all segments except for the female analysis that selected inappropriate business location as part of the top five factors (see Table 18).

3) Inadequate finance was identified as the contributing factor with the second highest magnitude by all the other segments except for the female data analysis that selected lack of entrepreneurial skills (see Table 19). 
Table 17. Participants response to finding \#13.

\begin{tabular}{|c|c|c|c|c|c|c|c|}
\hline Finding \# & Question \# & Main Idea & Strongly agree & Agree & $\begin{array}{l}\text { Neither agree } \\
\text { nor disagree }\end{array}$ & Disagree & $\begin{array}{l}\text { Strongly } \\
\text { disagree }\end{array}$ \\
\hline \multirow{4}{*}{13} & Q31 & Business failure/ignoring competition & 86 & 116 & 19 & 13 & 3 \\
\hline & Q32 & Business sustainability/business competition & 107 & 96 & 17 & 11 & 6 \\
\hline & & & Over $75 \%$ & $50 \%-75 \%$ & $25 \%-49 \%$ & \multicolumn{2}{|c|}{ Less than $25 \%$} \\
\hline & Q33 & Business failure/ignoring competition & 108 & 80 & 36 & \multicolumn{2}{|c|}{13} \\
\hline
\end{tabular}

Table 18. Top five contributing factors per segment.

\begin{tabular}{|c|c|c|c|c|c|c|c|c|c|}
\hline \multirow{3}{*}{$\begin{array}{l}\text { No. } \\
1\end{array}$} & \multirow{3}{*}{$\begin{array}{l}\text { Contributing Factors } \\
\text { Poor business planning }\end{array}$} & \multicolumn{8}{|c|}{ ANALYSIS SEGMENTS-Top Five Contributing Factors } \\
\hline & & \multirow{2}{*}{$\begin{array}{c}\text { General } \\
\text { Yes }\end{array}$} & \multirow{2}{*}{$\begin{array}{c}\text { Business } \\
\text { Student }\end{array}$} & \multirow{2}{*}{$\begin{array}{c}\text { Business } \\
\text { Person }\end{array}$} & \multirow{2}{*}{$\begin{array}{l}\text { Male } \\
\text { Yes }\end{array}$} & \multirow{2}{*}{$\begin{array}{c}\text { Female } \\
\text { Yes }\end{array}$} & \multicolumn{3}{|c|}{50 yrs Above 31 yrs - 49 yrs 18 yrs - 30 yrs } \\
\hline & & & & & & & Yes & Yes & Yes \\
\hline 2 & Lack of entrepreneurial skills & Yes & Yes & Yes & Yes & Yes & Yes & Yes & Yes \\
\hline 3 & Lack of customer relations & Yes & Yes & Yes & Yes & Yes & Yes & Yes & Yes \\
\hline 4 & Management Incompetence & Yes & Yes & Yes & Yes & Yes & Yes & Yes & Yes \\
\hline 5 & Inadequate financing & Yes & Yes & Yes & Yes & No & Yes & Yes & Yes \\
\hline 6 & ignoring competition & No & No & No & No & No & No & No & No \\
\hline 7 & Inappropriate business location & No & No & No & No & Yes & No & No & No \\
\hline 8 & Lack of adequate cash flow & No & No & No & No & No & No & No & No \\
\hline 9 & Lack of employee's satisfaction & No & No & No & No & No & No & No & No \\
\hline 10 & $\begin{array}{l}\text { Lack of government support } \\
\text { and empowerment role }\end{array}$ & No & No & No & No & No & No & No & No \\
\hline
\end{tabular}

Table 19. Ranking of contributing factors per segment.

\begin{tabular}{|c|c|c|c|c|c|c|c|c|c|}
\hline \multirow[b]{2}{*}{ No. } & \multirow[b]{2}{*}{ Contributing Factors } & \multicolumn{8}{|c|}{ ANALYSIS SEGMENTS-Ranking of Contributing Factors from Highest to Lowest } \\
\hline & & General & $\begin{array}{l}\text { Business } \\
\text { Student }\end{array}$ & $\begin{array}{l}\text { Business } \\
\text { Person }\end{array}$ & Male & Female & 50 yrs Above & 31 yrs - 49 yrs & 18 yrs - 30 yrs \\
\hline 1 & Poor business planning & 1 st & 1 st & 1 st & 1 st & 1 st & 1 st & 1 st & 1 st \\
\hline 2 & Lack of entrepreneurial skills & 4 th & 4 th & 5 th & 4 th & 2nd & 4 th & 4 th & 4 th \\
\hline 3 & Lack of customer relations & 5 th & 5 th & 4 th & 5 th & 4 th & 5 th & 5 th & 5 th \\
\hline 4 & Management Incompetence & $3 r d$ & $3 r d$ & $3 r d$ & $3 r d$ & $3 r d$ & $3 r d$ & $3 r d$ & $3 r d$ \\
\hline 5 & Inadequate financing & 2nd & 2nd & 2nd & 2nd & & 2nd & 2nd & 2nd \\
\hline 6 & Inappropriate business location & & & & & 5 th & & & \\
\hline
\end{tabular}

4) Management incompetence was identified as the contributing factor with the third highest magnitude by all the segments (see Table 19).

5) Lack of entrepreneurial skills was identified as the contributing factor with the fourth highest magnitude by all the other segments except for the female data analysis (as second) and the business person data analysis (as fifth) (see Table 
19).

6) Lack of customer relations was identified as the contributing factor with the fifth highest magnitude by all the other segments except for business person data analysis and the female data analysis (as fourth) (see Table 19).

7) In all the different segments of analyses, participants accepted that the contributing factors are controllable except for "Lack of government support and empowerment role" that the findings revealed to be uncontrollable by all; "Lack of entrepreneurial skills" which was accepted by business persons, females and participants between the age range of 31 to 49 years old as uncontrollable; and "Lack of adequate cash flow" that the findings revealed to be uncontrollable by the 50 years above analysis (see Table 20).

8) The majority of the participants in all the different segments strongly agree and agree to all the Likert scale questions. They also accepted over $75 \%$ and $50 \%$ - 75\% for all the percentage rating questions. The rest of the other answer options were selected at minimal frequency which signifies that the participants accepted that the factors that were investigated to be responsible for the failure of small businesses in Liberia are correct. This can be seen in Tables 8-17.

\subsection{Research Findings and Literature Review}

From the literature review, it was stated that "one of the major reasons for business failure is due to poor business planning" (Schaefer, 2019). This was clearly demonstrated in the research findings. Poor business planning was identified as the main contributing factor to the failure of small businesses in Liberia. The research findings revealed that most proprietors of small businesses in Liberia do not plan properly. They depend on sales to run the business and do not forecast

Table 20. Contributing factors control measures findings per segment.

\begin{tabular}{|c|c|c|c|c|c|c|c|c|c|}
\hline \multirow[b]{2}{*}{ No. } & \multirow[b]{2}{*}{ Contributing Factors } & \multicolumn{8}{|c|}{ ANALYSIS SEGMENTS } \\
\hline & & General & $\begin{array}{l}\text { Business } \\
\text { Student }\end{array}$ & $\begin{array}{l}\text { Business } \\
\text { Person }\end{array}$ & Male & Female & 50 yrs Above & 31 yrs -49 yrs & 18 yrs - 30 yrs \\
\hline 1 & Poor business planning & $\mathrm{C}$ & $\mathrm{C}$ & $\mathrm{C}$ & $\mathrm{C}$ & $\mathrm{C}$ & $\mathrm{C}$ & $\mathrm{C}$ & $\mathrm{C}$ \\
\hline 2 & Lack of entrepreneurial skills & $\mathrm{C}$ & $\mathrm{C}$ & UC & $\mathrm{C}$ & UC & $\mathrm{C}$ & UC & $\mathrm{C}$ \\
\hline 3 & Lack of customer relations & $\mathrm{C}$ & C & $\mathrm{C}$ & $\mathrm{C}$ & $\mathrm{C}$ & $\mathrm{C}$ & $\mathrm{C}$ & $\mathrm{C}$ \\
\hline 4 & Management Incompetence & $\mathrm{C}$ & $\mathrm{C}$ & $\mathrm{C}$ & $\mathrm{C}$ & $\mathrm{C}$ & $\mathrm{C}$ & $\mathrm{C}$ & $\mathrm{C}$ \\
\hline 5 & Inadequate financing & $\mathrm{C}$ & $\mathrm{C}$ & $\mathrm{C}$ & $\mathrm{C}$ & $\mathrm{C}$ & $\mathrm{C}$ & $\mathrm{C}$ & $\mathrm{C}$ \\
\hline 6 & ignoring competition & $\mathrm{C}$ & $\mathrm{C}$ & $\mathrm{C}$ & $\mathrm{C}$ & $\mathrm{C}$ & $\mathrm{C}$ & $\mathrm{C}$ & $\mathrm{C}$ \\
\hline 7 & Inappropriate business location & $\mathrm{C}$ & $\mathrm{C}$ & $\mathrm{C}$ & $\mathrm{C}$ & $\mathrm{C}$ & $\mathrm{C}$ & $\mathrm{C}$ & $\mathrm{C}$ \\
\hline 8 & Lack of adequate cash flow & $\mathrm{C}$ & $\mathrm{C}$ & $\mathrm{C}$ & $\mathrm{C}$ & $\mathrm{C}$ & UC & $\mathrm{C}$ & $\mathrm{C}$ \\
\hline 9 & Lack of employees satisfaction & $\mathrm{C}$ & $\mathrm{C}$ & $\mathrm{C}$ & $\mathrm{C}$ & $\mathrm{C}$ & $\mathrm{C}$ & $\mathrm{C}$ & $\mathrm{C}$ \\
\hline 10 & $\begin{array}{l}\text { Lack of government support } \\
\text { and empowerment role }\end{array}$ & UC & UC & UC & UC & UC & UC & UC & UC \\
\hline
\end{tabular}

Key: Controllable $=$ C Partially Controllable $=$ PC Uncontrollable $=$ UC. 
or plan ahead (Carter, 2019; Burns \& Dewhurst, 1996). Poor businesses planning prevents the owners or managers of small businesses from assessing the probability of their product or service failure and what to do to mitigate any problem that may arise (Walters, 2019). The research findings identified inadequate financing among the top five contributing factors to the failure of small businesses in Liberia. The research findings revealed that the failure of most small businesses in Liberia is due to lack of proper financial support and the unconsciousness of raising capital by the owners (Skripak et al., 2016). The choice of inadequate financing among the top five contributing factors is a true reflection of the actual financial status of most small businesses in Liberia because they don't have the financial power to sustain the business (Doe, 2006). Most people don't have the required funds to start a small business or even the liquid assets required by banks and other financial institutes to obtain loan for the business (Mason, 2020). They use their own cash or the resource belonging to the family to start the business (Attard, 2019). When the business starts to operate, they rely on the revenue generated to sustain their family (Petersen \& Seidel, 2019).

Another contributing factor that was identified among the top five in the research findings is management incompetence. The research findings revealed that most of the small businesses in Liberia lack staff with the required experience and expertise to effectively run a business. Small businesses are mostly initiated by people that don't have the rightful knowledge to run a business (Adisa et al., 2014). Management incompetence influences the performance of the business (Adisa et al., 2014). Previous studies have also identified management incompetence as a major cause of small business failure (Knotts et al., 2003). Management incompetence results in decline in profits, reduction of revenues and rising costs (Basu, 2020). Most small businesses fail because their management is unable to position their products in a way that it attracts more customers and maintain the existing ones. They are also not effective in responding to the introduction of new products by their competitors in the market (Basu, 2020). This reduces sales and affects the bottom line of the business. Lack of entrepreneurial skills was also identified in the top five contributing factors from the research findings. The research findings revealed that most of the owners of small businesses in Liberia lack entrepreneurial skills which are very important for the ignition and control of small businesses to prevent failure. They are unable to create production opportunities and even to apply technological improvement by inventing new products, or processes (Timmons \& Spinelli, 2007), which will give them competitive advantage. Studies have revealed that the growth and operations of small businesses are influence by entrepreneurial skills (Abdul, 2018). Entrepreneurial skills are needed by small business proprietors to analyze situations, opportunities and the environments (Kuratko \& Hodgetts, 2008). The skills are needed to plan, control and assess the risks and associated rewards of the business before taking any action (Kuratko \& Hodgetts, 2008). Entrepreneurial skills are the most important basic skills that is needed for small busi- 
nesses to be successful (Marivate, 2014).

Lastly, lack of customer relations was highlighted as one of the top five factors that causes small businesses to fail in Liberia. The research findings revealed that most small businesses in Liberia fail due to lack of customer relations as a result of lack of daily contact with customers, lack special promotions and lack of new features. The literature review helps us to understand that the profitability of small businesses and the delivery of value to customers is very essential for the business to remain in existence (Babu, 2012). If the customers are not comfortable with how their needs have been addressed or they noticed that their requests are not been handle politely or in a professional manner, is less likely that the customers will continue to buy from you (Francis, 2020). This will have a serious negative effect on the bottom line of the business. Lack of customer relations can lead to the prevention of getting new customers because of the testimonies given to them by the old customers on your poor customer relations (Burch, 2019).

\section{Conclusions and Recommendations}

\subsection{Research Outcome and Research Objectives}

This study was conducted to achieve four major objectives. Below are the research outcomes to every objective that was targeted to be achieved during the research:

1) To critically analyze the factors responsible for the failure of small businesses in Liberia.

The research findings identified ten contributing factors responsible for the failure of small businesses in Liberia. Out of the ten contributing factors, the top five include Poor Business Planning, Lack of Entrepreneurial Skills, Lack of Customer Relations, Management Incompetence and Inadequate Financing. Poor business planning was identified as the main contributing factor. If the proprietors of small businesses don't forecast or plan ahead, their businesses won't succeed (Carter, 2019). According to the research findings, inadequate financing is one of the major problems encountered by small businesses (Skripak et al., 2016). If the business does not have a strong and stable financial support it will fail (Mehralizadeh \& Sajady, 2005). Management incompetence is another key factor identified to lead to small business failure. Without management competence, businesses will perform poorly (Adisa et al., 2014). Lack of entrepreneurial skills can prevent the growth of business and impede the ability of the business to compete with others (Timmons \& Spinelli, 2007; Abdul, 2018). Lack of customer relations results in reduction in customers over a period of time because of dissatisfaction (Francis, 2020). For small businesses to succeed, the relationship between the customers and the business staff is very essential (Babu, 2012).

2) To evaluate the extent to which the factors identified as being responsible for the failure of small businesses in Liberia affects the businesses.

The research findings revealed the impact of the contributing factors on small 
businesses in Liberia. This was reflected in the analysis of the participant's responses through the questionnaire. Some of the findings of the extent to which the contributing factors affect the small businesses were measured in percentages while the others express the feelings of the participants. The research findings revealed that majority of the participants strongly agree and agree that the ten contributing factors identified by the research lead to small business failure in Liberia. They also accepted that most of the small businesses in Liberia fail as a result of over $75 \%$ to $50 \%$ of the impact of the ten contributing factors identified by the research.

3) To critically assess whether the factors identified to be responsible for the failure of small businesses in Liberia are controllable or uncontrollable.

It was established that nine out of ten of the contributing factors identified to be responsible for the failure of small businesses in Liberia are controllable, except for "Lack of government support and empowerment role". The nine controllable factors are Poor business planning, Lack of entrepreneurial skills, Lack of customer relations, Management Incompetence, Inadequate financing, Ignoring competition, Inappropriate business location, Lack of adequate cash flow and Lack of employee's satisfaction.

4) To develop a guideline that will provide possible solution to reduce the rate of failure of small businesses in Liberia.

This objective has to do with the development of recommendations that can be applied to reduce the failure rate of small businesses in Liberia. Recommendations are provided to avoid poor business planning and lack of strategic planning (Zhou, 2017; Gumel, 2017). It is recommended that small business proprietors required entrepreneurship skill-sets and guidance from entrepreneurs to avoid business failure due to lack of entrepreneurial skills (Cooney, 2012; Dunn, 2016). It is also recommended that businesses should enforce good customer relation policies and develop an effective communication medium with the customers (Sibanda \& Ndhlela, 2018; Mbonyane, 2006). To avoid management incompetence, it is recommended to employ competent managers and implement a good training and staff development program (Adisa et al., 2014; Mbonyane, 2006). Lastly, it is recommended for small business proprietors to forecast the correct financial requirement for the business and include it into the business plan to avoid business failure due to inadequate financing (Mason, 2020). Other recommendations include the acquisition of loan from banks or financial institutions and the proper usage of revenue generated for the business (Mehralizadeh \& Sajady, 2005; Petersen \& Seidel, 2019).

\subsection{Recommendations}

To address the top five contributing factors responsible for the failure of small businesses, below are recommendations that can be applied to small businesses to ensure long existence, profitability and sustainability:

1) Poor Business Planning-To avoid the problem of poor business planning, 
small business proprietors should ensure to conduct accurate business planning that permits the develop of a standard business plan that covers all the required areas of the business and not incorporating information that are not even related to the business for implementation (Zhou, 2017; Schaefer, 2019). They should also ensure that strategic planning is applied to the business activities to prevent poor business performance (Gumel, 2017). These recommendations are not expensive or difficult to implement. They are very essential to prevent small business failure and they can be implemented in a short period of time. However, if the proprietors are not competent to develop a standard business plan, these recommendations cannot be implemented correctly.

2) Lack of Entrepreneurial Skills-For small business proprietors to address the issue of lack of entrepreneurial skills, they need to develop inter discipline, the ability to take risk, be innovative, be change-oriented and be persistence (Cooney, 2012). They also need to improve their communication, leadership and negotiation skills and that of their employees (Dunn, 2016). These recommendations required long term implementation and investment because skill acquiring process is time consuming and costly. The short term recommendation is to contract, hire or seek the guidance of experience entrepreneurs to help in making high level decisions for the business (Dunn, 2016). This might be expensive depending on the choice of the proprietor but it is a quick solution and has to be implemented to save the business from failing.

3) Lack of Customer Relations-To solve the problem of lack of customer relations, small business proprietors need to create an effective communication medium with the customers to enable them to communicate to the staff of the business regularly, so that complains and feedback on products or services can be addressed urgently (Mbonyane, 2006; Soliman, 2011). They also need to develop a business culture that rewards best employees for their effective contribution towards good customer relations (DiScipio, 2017), and develops a good customer relations policy and empowers the staff to implement the policy effectively (Sibanda \& Ndhlela, 2018). These are short term recommendations, they are feasible to be implemented and they are cost effective. These recommendations are of high priority, but there are challenges to face, especially where you have to change the culture of the staff. The long term recommendation is to provide special promotions, price changes and offer new product features that will attract the customers and keep their loyalty to continue doing business with you (The Small Business Advisor, 1999; Mbonyane, 2006). This action is costly, workable and time consuming. However, it is the action that is needed to sustain the relationship of the customers and the business.

4) Management Incompetence-To prevent management incompetence small business proprietors should employ managers with the rightful skills and years of experience to take care of their companies, especially in cases where they don't have sufficient knowledge to manage the business (Adisa et al., 2014; Mbonyane, 2006). To implement this action is easy, quick and not expensive. It 
is very crucial for businesses to be managed by people with the correct skills. The critical point to consider for this recommendation is the effectiveness of the recruitment process. A long term solution is for proprietors of small businesses to ensure that resources are available at all times for the training and development of staff (Adisa et al., 2014). This required long term investment in skills development of the staff, which is expensive, but it is required to keep the business in existence and competitive.

5) Inadequate Financing - To solve the problem of inadequate financing, small business proprietors should not use business generated revenue for non-business related activities (Petersen \& Seidel, 2019). They should employ people with the required qualification and competence to manage the financial affairs of the business (Mbonyane, 2006). These recommendations can be implemented within a short period. They are not expensive and they are not difficult to be implemented. The major challenge to note is the issue of trust. For long term recommendations, small business proprietors should acquire loan from financial institutions that provide loan for business purpose (Mehralizadeh \& Sajady, 2005). They can also incorporate shareholders into the business, to help with financial support to meet the business needs (Mehralizadeh \& Sajady, 2005). The government and business associations to work with financial institutions within Liberia to develop a reasonable loan scheme with affordable collateral requirements and interest-rate, that enables small businesses to operate, pay back the loan and still make profit (Mehralizadeh \& Sajady, 2005). These recommendations are feasible but require a lot of time for negotiation, policy development and actual implementation. It is costly because of the interest rate but if successful, they can make the business to be sustainable.

\subsection{Suggestions for Further Studies}

There are more opportunities for future research on the failure of small businesses in Liberia. The outcomes of this research will help in reducing the literature gap for the failure of small businesses. Below are some areas for future research:

- Why most small businesses in Liberia don't have a proper business plan?

- Why most business persons and business students in Liberia within the age range of 50 years above believe that lack of adequate cash flow is uncontrollable for small businesses in Liberia?

- Why most business persons and business students in Liberia within the age range of 31 to 49 years believe that lack of entrepreneurial skills is uncontrollable for small businesses in Liberia?

- How to create a sustainable and profitable small business in Liberia?

\section{Acknowledgements}

I firstly want to give thanks and praises to God Almighty for keeping me alive and giving me the ability to successfully complete this study. My deepest grati- 
tude goes to my wife and children. I also want to extend my thanks and appreciation to my MBA project supervisor Dr. David Mankin for guiding me throughout the period of my dissertation project. Finally, I want to appreciate all the participants that took part in this research, and all those that supported me in any way to successfully complete this study.

\section{Conflicts of Interest}

The author declares no conflicts of interest regarding the publication of this paper.

\section{References}

Abdul, O. E. (2018). Entrepreneurial Skills and Growth of Small and Medium Enterprise (SMEs): A Comparative Analysis of Nigerian Entrepreneurs and Minority Entrepreneurs in the UK. International Journal of Academic Research in Business and Social Sciences, 8, 28-46. https://doi.org/10.6007/IJARBSS/v8-i5/4083

Adisa, T. A., Abdulraheem, I., \& Mordi, C. (2014). The Characteristics and Challenges of Small Businesses in Africa: An Exploratory Study of Nigerian Small Business Owners. Economic Insights - Trends and Challenges, 3, 1-14.

Akhtar, I. (2016). Research Design. ResearchGate. https://www.researchgate.net/publication/308915548_Research_Design https://doi.org/10.2139/ssrn.2862445

Alaye-Ogan, E. (2012). A Practical Guide to Running Successful Small Businesses in Nigeria: Challenges, Peculiarities, and Effective Resolution Support. Deutschland: Lambert Academic Publishing.

Almeida, F., Faria, D., \& Queirós, A. (2017). Strengths and Limitations of Qualitative and Quantitative Research Methods. European Journal of Education Studies, 3, 2501-1111.

Al-Shaikh, F. N. (1998). Factors for Small Business Failure in Developing Countries. Journal of Competitiveness Studies, 6. https://www.questia.com/library/journal/1P3-38371342/factors-for-small-business-fail ure-in-developing-countries

Altman, E. I. (1968). Financial Ratios, Discriminant Analysis and the Prediction of Corporate Bankruptcy. The Journal of Finance, 23, 589-609. https://doi.org/10.1111/j.1540-6261.1968.tb00843.x

Attard, J. (2019). Sources of Small Business Financing. Business Know-How. https://www.businessknowhow.com/money/financingsource.htm

Babu, G. C. (2012). The Impact of Customer Relationship Management on Small and Medium Enterprises Performance. International Research Journal of Commerce Arts and Science, 3, 2319-9202.

Banker, R., Huang, R., \& Natrajan, R. (2009). Incentive Contracting and Value Relevance of Earnings and Cash Flows. Journal of Account Research, 47, 647-678. https://doi.org/10.1111/j.1475-679X.2009.00335.x

Basu, C. (2020). 10 Signs of Incompetent Management. Chron. https://smallbusiness.chron.com/10-signs-incompetent-management-31121.html

Benn, S., Abratt, R., \& O’Leary, B. (2016). Defining and Identifying Stakeholders: Views from Management and Stakeholders. South African Journal of Business Management, 47, 1-11. https://doi.org/10.4102/sajbm.v47i2.55 
Bhatia, N. (2018). Your Guide to Qualitative and Quantitative Data Analysis Methods. Altan.

https://humansofdata.atlan.com/2018/09/qualitative-quantitative-data-analysis-metho ds/

Borden, N. (1964). The Concept of Marketing Mix. Journal of Advertising Research, 4, 2-7.

Bradley, L. (2013). Primary Data. GetRevising. https://getrevising.co.uk/grids/primary data 3

Brown, M. (2018). How Important Are Small Businesses to Local Economies? Chron. https://smallbusiness.chron.com/important-small-businesses-local-economies-5251.ht $\underline{\mathrm{ml}}$

Bryman, A. (2008). Social Research Methods. Oxford: Oxford University Press.

Bryman, A., \& Bell, E. (2015). Business Research Methods (4th ed.). Oxford: Oxford University Press.

Building Markets (2016). Liberian Businesses: The Engines of Economic Recovery and Growth. United States Agency for International Development.

Building Markets (2017). Final Activity Report: Sustainable Marketplace Initiative-Liberia. United States Agency for International Development.

Burch, J. (2019). How Does Poor Customer Service Affect a Business? YourBusiness. https://yourbusiness.azcentral.com/poor-customer-service-affect-business-3062.html

Burns, P., \& Dewhurst, J. (1996). Small Business and Entrepreneurship (2nd ed.). London: Macmillan Press Ltd. Publishing.

Bushe, B. (2019). The Causes and Impact of Business Failure among Small to Micro and Medium Enterprises in South Africa. Africa's Public Service Delivery and Performance Review, 7, 2310-2195. https://doi.org/10.4102/apsdpr.v7i1.210

Business Week (1971). Sears Identity Crisis (pp. 52-57).

Carter, P. (2019). 11 Reasons Why Most Entrepreneurs Fail. Forbes. https://www.forbes.com/sites/forbescoachescouncil/2019/07/05/11-reasons-why-mostentrepreneurs-fail/\#19da2af31b7b

Chetty, P. (2016). Importance of Research Approach in a Research. Project Guru. https://www.projectguru.in/publications/selecting-research-approach-business-studies/

Chong, K. W. (2003). The Role of Pricing in Relationship Marketing-A Study of the Singapore Heavy Equipment Spare Parts Industry. PhD Dissertation, Adelaide: University of South Australia, International Graduate School of Management.

Cohen, L., Manion, L., \& Morrison, K. (2007). Research Methods in Education (6th ed.). London: Routledge. https://doi.org/10.4324/9780203029053

Cooney, T. M. (2012). Entrepreneurship Skills for Growth-Orientated Businesses. Danish Business Authority. http://www.oecd.org/cfe/leed/cooney entrepreneurship skills HGF.pdf

Cromie, S., \& John, S. (1983). Irish Entrepreneurs: Some Personal Characteristics. Journal of Occupational Behaviour, 4, 317-324.

Crotty, M. (2003). The Foundation of Social Research: Meaning and Perspective in the Research Process. Thousand Oaks, CA: Sage.

Datt, S., \& Chetty, P. (2016). Defining a Research Strategy. Project Guru. https://www.projectguru.in/publications/research-strategy-business-studies/

David, J. (2016). Differences between Deductive and Inductive Approaches to Research. 
Howandwhat. https://www.howandwhat.net/differences-deductive-inductive/

Debois, S. (2019). 10 Advantages and Disadvantages of Questionnaires. SurveyAnyplace. https://surveyanyplace.com/questionnaire-pros-and-cons/

Didonet, S., Simmons, G., Díaz-Villavicencio, G., \& Palmer, M. (2012). The Relationship between Small Business Market Orientation and Environmental Uncertainty. Marketing Intelligence and Planning, 30, 757-779. https://doi.org/10.1108/02634501211273841

DiScipio, T. (2017). 5 Worst Side Effects of Bad Customer Service (and How to Avoid Them). Impact.

https://www.impactbnd.com/blog/5-dangerous-side-effects-of-bad-customer-service

Dodoo, L. (2020). Massive Economic Meltdown in Liberia Leading to Closure of Small and Medium Size Enterprises. Front Page Africa.

https://frontpageafricaonline.com/business/economy/liberia-local-foreign-owned-busi nesses-shutting-down-amid-deteriorating-economy/

Doe, J. F. (2006). Why Many Liberian-Owned Businesses Fail: A First Person Account. The Perspective. https://www.theperspective.org/articles/0109200602.html

Dudovskiy, J. (2018). The Ultimate Guide to Writing a Dissertation in Business Studies: A Step-by-Step Assistance.

Dunn, C. W. (2016). 12 Effective Ways to Build Entrepreneurial Skills That Matter. Entrepreneur Europe. https://www.entrepreneur.com/article/279465

Ernest, P. (1994). An Introduction to Research Methodology and Paradigms. Exeter: RSU, School of Education, University of Exeter.

Fatoki, O. (2014). The Causes of the Failure of New Small and Medium Enterprises in South Africa. Mediterranean Journal of Social Sciences, 5, 2039-9340. https://doi.org/10.5901/mjss.2014.v5n20p922

Flint, M. (2019). Cash Flow: The Reason $82 \%$ of Small Businesses Fail. Preferred CFO. https://www.preferredcfo.com/cash-flow-reason-small-businesses-fail/

Francis, K. A. (2020). How Lack of Customer Service Can Impact a Business. Chron. https://smallbusiness.chron.com/lack-customer-service-can-impact-business-2088.html

Gartenstein, D., \& Seidel, M. (2019). Why Is Strategic Planning Important to a Business? Chron. https://smallbusiness.chron.com/strategic-planning-important-business-2671.html

Gaughan, P. A. (2015). Mergers, Acquisitions, and Corporate Restructurings (6th ed.). Hoboken, NJ: John Wiley and Sons, Inc.

Giddens, A. (Ed.) (1974). Positivism and Sociology. London, England: Heinemann Educational Books, Ltd.

Glen, S. (2015). Likert Scale Definition and Examples. Statistics How To. https://www.statisticshowto.datasciencecentral.com/likert-scale-definition-and-exampl es/

Glen, S. (2016). Reliability and Validity in Research: Definitions, Examples. Data Science Central.

https://www.statisticshowto.datasciencecentral.com/reliability-validity-definitions-exa mples/

Goi, C. L. (2009). A Review of Marketing Mix: 4Ps or More. International Journal of Marketing Studies, 1, 2-15. https://doi.org/10.5539/ijms.v1n1p2

Grix, J. (2010). The Foundations of Research. London: Palgrave Macmillan. https://doi.org/10.1007/978-0-230-36490-5 
Gumel, B. I. (2017). Strategizing for Sustaining Small Business Enterprises in Nigeria. IOSR Journal of Business and Management, 19, 8-25.

Gunto, M., \& Alias, M. H. (2013). SMEs development in Malaysia: Lessons for Libya. Prosiding Perkem VIII, 3, 1521-1530.

Gupta, A. (2013). Environment \& PEST Analysis: An Approach to External Business Environment. International Journal of Modern Social Sciences, 2, 34-43.

Hanlon, A. (2019). How to Use the 7Ps Marketing Mix. Smart Insight. https://www.smartinsights.com/marketing-planning/marketing-models/how-to-use-th e-7ps-marketing-mix/

Hecht, J. (2015). The 5 Worst Cash-Flow Mistakes Small-Business Owners Make. Entrepreneur Europe. https://www.entrepreneur.com/article/249020

Helm, R., \& Gritsch, S. (2014). Examining the Influence of Uncertainty on Marketing Mix Strategy Elements in Emerging Business to Business Export-Markets. International Business Review, 23, 418-428. https://doi.org/10.1016/j.ibusrev.2013.06.007

Horton, M. (2019). The 4 Most Common Reasons a Small Business Fails. Investopedia. https://www.investopedia.com/articles/personal-finance/120815/4-most-common-reas ons-small-business-fails.asp

Hubbard, R. T., \& Hailes Jr., W. D. (1988). Small Business Management (4th ed.). New York: Delmar Publishers.

Hunter, W., \& Tietyen, D. (1997). Business to Business Marketing: Creating a Community of Customers. Lincolnwood, IL: McGraw-Hill Professional.

Hussey, J., \& Hussey, R. (1997). Business Research: A Practical Guide for Undergraduate Students. London: Macmillan Publishing.

Jenkins, A. S., \& McKelvie, A. (2016). What Is Entrepreneurial Failure? Implications for Future Research. International Small Business Journal, 34, 176-188. https://doi.org/10.1177/0266242615574011

Johnson, R. B., \& Onwuegbuzie, A. J. (2004). Mixed Methods Research: A Research Paradigm Whose Time Has Come. Educational Researcher, 33, 14-26. https://doi.org/10.3102/0013189X033007014

Jones, O., \& Tilley, F. (2003). Competitive Advantage in SMEs: Organizing for Innovation and Change. San Francisco, CA: John Wiley \& Sons.

Kabir, S. M. S. (2016). Methods of Data Collection. In Basic Guidelines for Research: An Introductory Approach for All Disciplines (Chap. 9, pp. 201-275). Bangladesh: Book Zone Publication.

https://www.researchgate.net/publication/325846997 METHODS OF DATA COLLE CTION

Kanayo, O., Jumare, F., \& Nancy, S. (2013). Challenges of Microfinance Access in Nigeria: Implication for Entrepreneurship Development. Mediterranean Journal of Social Science, 4, 611-618. https://doi.org/10.5901/mjss.2013.v4n6p611

Kawalczyk, D. (2003). Purposes of Research: Exploratory, Descriptive \& Explanatory. Study.com.

https://study.com/academy/lesson/purposes-of-research-exploratory-descriptive-expla natory.html

Knotts, T. L., Jones, S. C., \& Udell, G. G. (2003). Small Business Failure: The Role of Management Practices and Product Characteristics. ResearchGate.

Kotler, P., \& dan Armstrong, K. (2009). Prinsip-prinsip Pemasaran (3rd ed.). Jakarta: Erlangga. 
Kotler, P., \& Keller, K. L. (2009). Manajemen Pemasaran (13th ed.). Jakarta: Penerbit Erlangga.

Kozak, S. (2017). The Role and Importance of the Small Business Sector in the Economic Development of the Mazowieckie Province. ResearchGate.

Kuratko, D. F., \& Hodgetts, R. M. (2008). Entrepreneurship in the Millennium. New Delhi, India: South Western, Akash Press.

Longair, T. C. A. (1983). Ratio Analysis and the Prediction of Business Failure. Research Project Submitted in Partial Fulfillment of the Requirements for the Degree of Master of Arts, Canada: The Department of Economics, Simon Fraser University https://pdfs.semanticscholar.org/ef07/dff17ad07dc6cc36a432ff308159cfc7cf10.pdf

Longenecker, J. G., Moore, C. W., \& Petty, J. W. (2003). Small Business Management: An Entrepreneurial Emphasis (12th ed.). Canada: Thomson.

Loo, P. T., \& Leung, R. (2016). A Service Failure Framework of Hotels in Taiwan: Adaptation of 7Ps Marketing Mix Elements. Journal of Vacation Marketing, 24, 79-100. https://journals.sagepub.com/doi/full/10.1177/1356766716682555 https://doi.org/10.1177/1356766716682555

Lotich, P. (2019). 10 Primary Functions of Managing a Small Business. Thriving Small Business. https://thethrivingsmallbusiness.com/small-business-management/

MacDonald, S. (2019). Why Customer Complaints Are Good for Your Business. SuperOffice. https://www.superoffice.com/blog/customer-complaints-good-for-business/

Maricica, M., \& Georgeta, V. (2012). Business Failure Risk Analysis Using Financial Ratios. Procedia-Social and Behavioral Sciences, 62, 728-732. https://doi.org/10.1016/j.sbspro.2012.09.123

Marivate, S. P. (2014). The Impact of Entrepreneurial Skills on the Viability and Long Term Survival of Small Businesses: A Case of the City of Tshwane, South Africa. European Journal of Business, Economics and Accountancy, 2, 53-72.

Mason, M. K. (2020). What Causes Small Businesses to Fail? Moyak. http://www.moyak.com/papers/small-business-failure.html

Mbonyane, B. L. (2006). An Exploration of Factors that Lead to Failure of Small Businesses in the Kagiso Township. College of Economic and Management Science. https://core.ac.uk/download/pdf/43165627.pdf

McCombes, S. (2019). Descriptive Research. Scribbr. https://www.scribbr.com/methodology/descriptive-research/

McGregor, A. (2004). My Own Business. http://m1.mny.co.za/4225686C004E64FC/(UNID)/AMAS4GAMML?OpenDocument

McLeod, S. (2018). Questionnaire: Definition, Examples, Design and Types. Simply Psychology. https://www.simplypsychology.org/questionnaires.html

McMillan, J. H., \& Schumacher, S. (2001). Research in Education: A Conceptual Introduction (5th ed.). New York: Longman.

Mehralizadeh, Y., \& Sajady, S. H. (2005). A Study of Factors Related to Successful and Failure of Entrepreneurs of Small Industrial Business with Emphasis on Their Level of Education and Training. Paper presented at the European Conference on Educational Research, University College Dublin. https://doi.org/10.2139/ssrn.902045

Meng, M. K. (2013). Overcoming the Cash Drought. The Business Times. http://search.proquest.com/docview/1458563426

Middleton, F. (2019). Reliability vs Validity: What's the Difference? Scribbr. https://www.scribbr.com/methodology/reliability-vs-validity/ 
millforbusiness.com (2018). Why Do Small Businesses Fail? 10 Major Reasons and 50 Best Solutions. Mill for Business.

https://www.millforbusiness.com/why-do-small-businesses-fail/

Ministry of Commerce and Industry (MoCI), Republic of Liberia (2010). Liberia Poverty Alleviation and Wealth Creation through Small Enterprise Development.

Mitchell, A. (2018). A Review of Mixed Methods, Pragmatism and Abduction Techniques. The Electronic Journal of Business Research Methods, 16, 103-116.

Mong, D. (2011). Follow the Cash: Lessons for Capstone Business Courses. Journal of Business \& Economics Research, 9, 33-44. https://doi.org/10.19030/jber.v9i12.6604

Mukherji, P., \& Albon, D. (2014). Research Methods in Early Childhood. Thousand Oaks, CA: Sage.

Murray, J. (2019). Cash Flow_How It Works to Keep Your Business Afloat. The Balance Small Business.

https://www.thebalancesmb.com/cash-flow-how-it-works-to-keep-your-business-afloat $\underline{-398180}$

Mutoko, W. R. (2014). Challenges of Access to Markets and Opportunities for Small, Medium and Micro Enterprises (SMMEs) in Botswana. European Scientific Journal, 10, 28-38.

Nikolić, N., Dhamo, Z., Schulte, P., Mihajlović, I., \& Kume, V. (2015). An Analysis of Factors Affecting Failure of SMEs. International May Conference on Strategic Management-IMKSM2015, Bor, Serbia, 29-31 May 2015, 174-192.

Nkuah, J. K., Tanyeh, J. P., \& Gaeten, K. (2013). Financing Small and Medium Enterprises (SMEs) In Ghana: Challenges and Determinants in Accessing Bank Credit. International Journal of Research in Social Sciences, 2, 12-25.

Olsen, E. (2019). Ten Common Causes of Business Failure. OnStrategy. https://onstrategyhq.com/resources/ten-common-causes-of-business-failure/

Perez, E. (2019). What Is Data Analysis and Its Methods? Utreee. https://www.utreee.com/what-is-data-analysis-and-its-methods\%EF\%BB\%BF/

Perry, C., \& Pendleton, W. (1983). Successful Small Business Management. Sydney: Pitman Publishing.

Petersen, L., \& Seidel, M. (2019). Financial Problems That Small Business Enterprises Face. Chron.

https://smallbusiness.chron.com/financial-problems-small-business-enterprises-face-3 $\underline{528 . h t m l}$

Pickle, H. B., \& Abrahamson, R. L. (1990). Small Business Management (5th ed.). New York: John Wiley \& Sons.

Pillemer, N. (2018). Understanding the Key Stages in the Business Life Cycle. Become. https://www.become.co/blog/understanding-key-changes-business-life-cycle/

Praveen, H., \& Showkat, N. (2017). Research Ethics. ResearchGate. https://www.researchgate.net/publication/318912804 Research Ethics

Prokopets, M., \& Shah, H. (2019). Why You Shouldn't Ignore Your Competitors. Product Habits. https://producthabits.com/stop-ignoring-competitors/

Rathod, M. K. (2016). A Study on Extended Marketing Mix. Advances in Economics and Business Management (AEBM), 3, 205-212.

Resnik, D. B. (2015). What Is Ethics in Research and Why Is It Important? National Institute of Environmental Health Sciences. 
https://www.niehs.nih.gov/research/resources/bioethics/whatis/index.cfm

Richards, K. (2003). Qualitative Inquiry in TESOL. Basingstoke: Palgrave Macmillan. https://doi.org/10.1057/9780230505056

Rodrigo (2017). Different Research Strategies You Can Use in Your Dissertation. The WritePass Journal.

https://writepass.com/journal/2017/06/dissertation-structure-different-research-strateg ies-you-can-use-in-your-dissertation/

Sageer, A., Rafat, S., \& Agarwal, P. (2012). Identification of Variables Affecting Employee Satisfaction and their Impact on the Organization. IOSR Journal of Business and Management (IOSR-JBM), 5, 32-39. https://doi.org/10.9790/487X-0513239

Salkind, N. J. (2003). Exploring Research. Upper Saddle River, NJ: Pearson Education BR.

Saunders, M. N. K., Lewis, P., \& Thonhill, A. (2009). Understanding Research Philosophies and Approaches. London: Pearson Education.

Saunders, M. N., Lewis, P., \& Thornhill, A. (2015). Research Methods for Business Students (7th ed.). London: Pearson Education.

Schaefer, P. (2019). Why Small Businesses Fail: Top 7 Reasons for Startup Failure. Business Know-How. https://www.businessknowhow.com/startup/business-failure.htm

Sharma, S., \& Mahajan, V. (1980). Early Warning Indicators of Business Failure. Journal of Marketing, 44, 80-89. https://doi.org/10.1177/002224298004400412

Sherman, F., \& Seidel, M. (2019). Why Is the Location of a Business Important? Chron. https://smallbusiness.chron.com/location-business-important-43239.html

Sibanda, V., \& Ndhlela, M. (2018). Customer Relationship Management as a Customer Retention Tool: A Case Study of OK Zimbabwe Limited. EPH-International Journal of Business and Management Science, 4, 2208-2190.

Sincero, S. M. (2012). Advantages and Disadvantages of Surveys. Explorable. https://explorable.com/advantages-and-disadvantages-of-surveys

Singh, S. (2018). Sampling Techniques. Towards Data Science. https://towardsdatascience.com/sampling-techniques-a4e34111d808

Skripak, J. S., Cortes, A., \& Walz, A. (2016). Entrepreneurship: Starting a Business. Saylor Foundation's.

https://vtechworks.lib.vt.edu/bitstream/handle/10919/70961/Chapter\%206\%20Entrepr eneurship\%20-\%20Starting\%20a\%20Business.pdf?sequence $=11$ \&isAllowed $=\mathrm{y}$

Snape, D., \& Spencer, L. (2003). The Foundations of Qualitative Research. Los Angeles, CA: Sage.

Soliman, H. S. (2011). Customer Relationship Management and Its Relationship to the Marketing Performance. International Journal of Business and Social Science, 2, 166-182.

Springer, K. (2017). Why Embezzlement Most Often Occurs at Small Businesses-And How to Prevent It from Happening to You. Entrepreneur.

https://www.entrepreneur.com/article/293726

Sukhraj, R. (2017). 4 Best Ways to Keep a Customer Happy \& Improve Customer Retention. Impact.

https://www.impactbnd.com/blog/the-importance-of-keeping-your-customers-happy

Summut-Bonnici, T., \& Galea, D. (2015). PEST Analysis. In Wiley Encyclopedia of Management. Hoboken, NJ: John Wiley \& Sons, Ltd. https://www.researchgate.net/publication/257303449 PEST analysis https://doi.org/10.1002/9781118785317.weom120113 
Taherdoost, H. (2016). Sampling Methods in Research Methodology; How to Choose a Sampling Technique for Research. International Journal of Academic Research in Management (IJARM), 5, 18-27. https://doi.org/10.2139/ssrn.3205035

Tawney, C., \& Levitsky, J. (2000). Small Entrepreneurs' Development as a Strategy for Reducing the Social Cost of Restructuring and the Privatization Process: Public and Private Initiatives, Interdepartmental Action Programme on Privatization, Restructuring and Economic Democracy. Working Paper IPPRED-6.

Thakurta, S. G., \& Chetty, P. (2015). Understanding Research Philosophy. Project Guru. https://www.projectguru.in/publications/research-philosophy/

The Centralian Advocate (2009). Cash Is Indeed King. ProQuest. http://search.proquest.com/docview/37611692

The New Dawn (2019). Liberia: LRA Awards Highest Taxpayers. YallAfrica. https://allafrica.com/stories/201907150569.html

The Small Business Advisor (1999). The Entrepreneur Magazine (2nd ed.). New York: John Wiley \& Sons.

Thompsell, A. (2018). A Brief History of the African Country of Liberia. ThoughtCo. https://www.thoughtco.com/brief-history-of-liberia-4019127

Timmons, J. A., \& Spinelli, S. (2007). New Venture Creation. Entrepreneurship in the 21st Century (7th ed.). New Delhi, India: Tata McGraw-Hill.

Tracy, B. (2005). Choosing a Product or Service to Sell. Entrepreneur. https://www.entrepreneur.com/article/78778

Trochim, W. M. K. (2020). Research Methods Knowledge Base. In Social Research Methods. https://socialresearchmethods.net/kb/descriptive-statistics/

Ucbasaran, D., Shepherd, D. A., Lockett, A., \& Lyon, S. J. (2013). Life after Business Failure: The Process and Consequences of Business Failure for Entrepreneurs. Journal of Management, 39, 163-202. https://doi.org/10.1177/0149206312457823

unctad.org (2002). United Nations Conference on Trade and Development. UNCTAD/ ITE/IIA/5. https://unctad.org/en/docs/iteiia5 en.pdf

Van Aardt, I., Van Aardt, C., \& Bezuidenhoud, S. (2002). Entrepreneurship and New Venture Management. Cape Town: Oxford University Press.

Van Horne, J. C. (1977). Financial Management and Policy (4th ed.). New York: Prentice-Hall, Inc.

Walters, N. (2019). 10 Reasons Why Small Businesses Fail and How to Avoid Them. Shopkeep. https://www.shopkeep.com/blog/why-small-businesses-fail

Walters. J. E. (1957). The Determination of Technical Solvency. Journal of Business, 30, 30-45. https://doi.org/10.1086/294129

Weitzel, W., \& Jonsson, E. (1989). Decline in Organizations: A Literature Integration and Extension. Administrative Science Quarterly, 34, 91-109. https://doi.org/10.2307/2392987

wpfsi.com (2019). Why Banks Don't Lend to Small Businesses. West Philadelphia Financial Services Institution. https://wpfsi.com/banks-dont-lend-small-businesses/

Zhou, M. (2017). 5 Most Common Problems of Startups and Their Solutions. Smallbizdaily. https://www.smallbizdaily.com/5-most-common-problems-of-startups-and-their-solut ions/ 


\section{Appendices}

\section{Research Questionnaire}

The primary purpose for conducting this research is to fulfill the requirement for Master's in Business Administration (MBA) degree. This research will also help to provide information on some of the major causes of the failure of small businesses in Liberia and possible solutions to prevent them from failing. The data collected from this questionnaire is accepted by the participant to be used for this research, and the researcher will ensure that the information provided are kept confidentially by protecting the identity of the participant.

Research Question: Why Most Small Businesses in Liberia Fail

Date:

Sex: $\quad$ Male ( ) Female ( )

Category: Business Person ( ) Business Student ()

Age Range: 18 yrs - 30 yrs ( ) 31 yrs - 49 yrs ( ) 50 years above ( )

Q1. Identify the top five factors responsible for the failure of small businesses in Liberia by ticking the box against each factor in the table below.

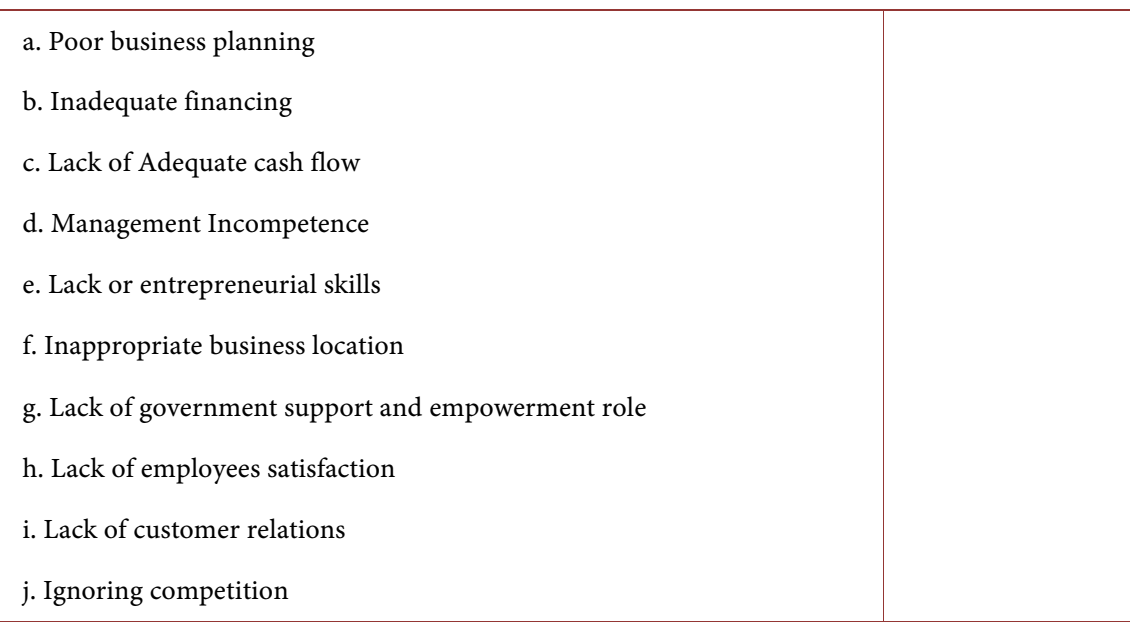

Q2. Arrange the top five factors identified in Q1 in descending order (from the most significant impact to the lowest)

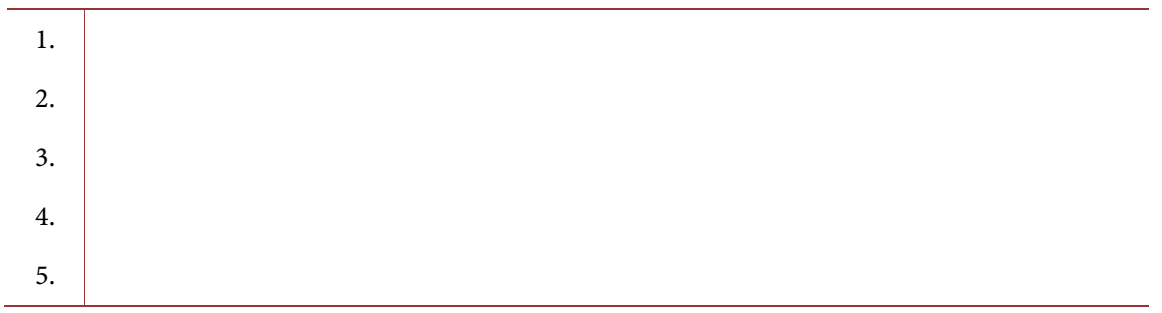


Q3. Indicate against each contributing factor in the table below whether they are (1) controllable, (2) uncontrollable or (3) partially controllable.

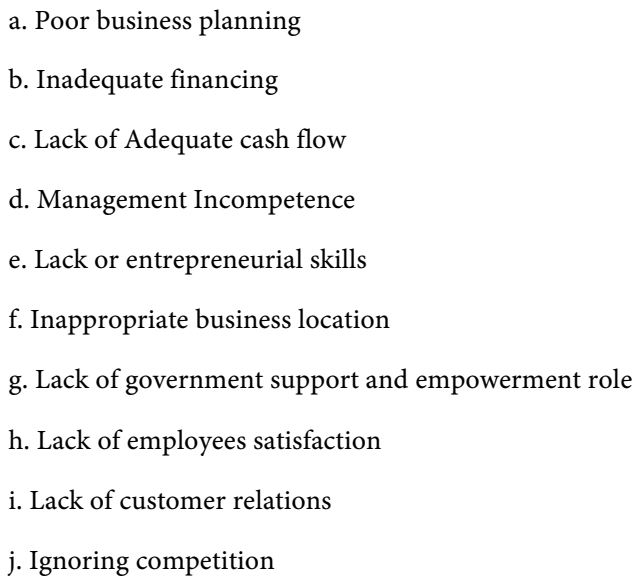

Q4. Most entrepreneurs of small business in Liberia do not plan properly.

Strongly agree ( ) Agree ( ) Neither agree nor disagree ( ) Disagree ( ) Strongly disagree ( )

Q5. Most small businesses in Liberia do not forecast or plan ahead. They depend on sales to run the business.

Strongly agree ( ) Agree ( ) Neither agree nor disagree ( ) Disagree ( ) Strongly disagree ( )

Q6. In your opinion what percentage of small businesses in Liberia operates without proper business plan?
a. Over $75 \%$
b. $50 \%-75 \%$
c. $25 \%-49 \%$
d. less than $25 \%$

Q7. The failure of many small businesses in Liberia is due to lack of proper financial support.

Strongly agree ( ) Agree ( ) Neither agree nor disagree ( ) Disagree ( ) Strongly disagree ( )

Q8. In your opinion what percentage of small business owners do not have the consciousness of raising capital?
a. Over $75 \%$
b. $50 \%-75 \%$
c. $25 \%-49 \%$
d. less than $25 \%$

Q9. Financing is the lifeline of every business.

Strongly agree ( ) Agree ( ) Neither agree nor disagree ( ) Disagree ( ) Strongly disagree ( )

Q10. Entrepreneurs of most small businesses in Liberia are not knowledgeable of projecting the cash flow of their business.

Strongly agree ( ) Agree ( ) Neither agree nor disagree ( ) Disagree ( ) Strongly disagree ( )

Q11. In your opinion what percentage of Liberian small business owners do not have the knowledge to correctly forecast their monthly cash flow?
a. Over $75 \%$
b. $50 \%-75 \%$
c. $25 \%-49 \%$
d. less than $25 \%$ 
Q12. Entrepreneurs of most small businesses in Liberia don't plan their future spending. There is no proper control of the business cash flow.

Strongly agree ( ) Agree ( ) Neither agree nor disagree ( ) Disagree ( ) Strongly disagree ( )

Q13. The failure of many small businesses in Liberia is due to management Inadequacy.

Strongly agree ( ) Agree ( ) Neither agree nor disagree ( ) Disagree ( ) Strongly disagree ( )

Q14. In your opinion what percentage of small businesses in Liberia has the issue of management inadequacy?
a. Over $75 \%$
b. $50 \%-75 \%$
c. $25 \%-49 \%$
d. less than $25 \%$

Q15. Most of the management of small businesses in Liberia lacks the experience and expertise to run the business.

Strongly agree ( ) Agree ( ) Neither agree nor disagree ( ) Disagree ( ) Strongly disagree ( )

Q16. The owners of most small businesses in Liberia lacks entrepreneur skills.

Strongly agree ( ) Agree ( ) Neither agree nor disagree ( ) Disagree ( ) Strongly disagree ( )

Q17. Business owners need entrepreneur skills to see the future.

Strongly agree ( ) Agree ( ) Neither agree nor disagree ( ) Disagree ( ) Strongly disagree ( )

Q18. Entrepreneur skills are very important for the initiation and control of small businesses to prevent failure.

Strongly agree ( ) Agree ( ) Neither agree nor disagree ( ) Disagree ( ) Strongly disagree ( )

Q19. The location of small businesses plays a very important role in terms of the success or failure of the business.

Strongly agree ( ) Agree ( ) Neither agree nor disagree ( ) Disagree ( ) Strongly disagree ( )

Q20. Some of the key factors to select an appropriate location for a small business is the buyer population and the amount of competitors.

Strongly agree ( ) Agree ( ) Neither agree nor disagree ( ) Disagree ( ) Strongly disagree ( )

Q21. In your opinion what percentage of small Liberian businesses select location based on the closeness to their resident or due to low rent?
a. Over $75 \%$
b. $50 \%-75 \%$
c. $25 \%-49 \%$
d. less than $25 \%$

Q22. It is the responsibility of the government to support and protect small businesses to grow by creating an enabling economic environment.

Strongly agree ( ) Agree ( ) Neither agree nor disagree ( ) Disagree ( ) Strongly disagree ( )

Q23. Most small businesses in Liberia fail because of lack of government support and empowerment. This includes lack of good road network, electricity, transportation and payment of high government taxes. 
Strongly agree ( ) Agree ( ) Neither agree nor disagree ( ) Disagree ( ) Strongly disagree ( )

Q24. Most small businesses in Liberia fail due to lack of implementation of special laws by the government that will give small domestic businesses leverage over foreign businesses.

Strongly agree ( ) Agree ( ) Neither agree nor disagree ( ) Disagree ( ) Strongly disagree ( )

Q25. One of the main reasons for the failure of small businesses in Liberia is the hiring of family members that lack the necessary business skills.

Strongly agree ( ) Agree ( ) Neither agree nor disagree ( ) Disagree ( ) Strongly disagree ( )

Q26. Lack of good salary scheme for employees of small businesses is a contributing factor to the failure of small businesses in Liberia. This result into major stealing of business assets.

Strongly agree ( ) Agree ( ) Neither agree nor disagree ( ) Disagree ( ) Strongly disagree ( )

Q27. In your opinion what percentage of small businesses lack employee satisfaction?
a. Over $75 \%$
b. $50 \%-75 \%$
c. $25 \%-49 \%$
d. less than $25 \%$

Q28. Most small businesses in Liberia fail due to lack of customer relations. Strongly agree ( ) Agree ( ) Neither agree nor disagree ( ) Disagree ( ) Strongly disagree ( )

Q29. Most small businesses in Liberia lack daily contact with customers, lack special promotions, and lack of new features.

Strongly agree ( ) Agree ( ) Neither agree nor disagree ( ) Disagree ( ) Strongly disagree ( )

Q30. In your opinion what percentage of small businesses lack customer relations?
a. Over $75 \%$
b. $50 \%-75 \%$
c. $25 \%-49 \%$
d. less than $25 \%$

Q31. Most small businesses in Liberia fail because they ignore competition.

Strongly agree ( ) Agree ( ) Neither agree nor disagree ( ) Disagree ( ) Strongly disagree ( )

Q32. It is very vital to focus on your competitor as an entrepreneur to sustain your business.

Strongly agree ( ) Agree ( ) Neither agree nor disagree ( ) Disagree ( ) Strongly disagree ( )

Q33. In your opinion what percentage of small businesses in Liberia ignore competition?
a. Over $75 \%$
b. $50 \%-75 \%$
c. $25 \%-49 \%$
d. less than $25 \%$ 